\title{
Revisiting factors controlling methane emissions from high-Arctic tundra
}

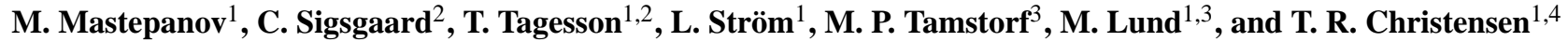 \\ ${ }^{1}$ Department of Physical Geography and Ecosystem Science, Lund University, Sweden \\ ${ }^{2}$ Center for Permafrost (CENPERM), Department of Geosciences and Natural Resource Management, \\ University of Copenhagen, Denmark \\ ${ }^{3}$ Arctic Research Centre, Bioscience, Aarhus University, Denmark \\ ${ }^{4}$ Greenland Climate Research Centre, Nuuk, Greenland
}

Correspondence to: M. Mastepanov (mikhail.mastepanov@nateko.lu.se)

Received: 23 October 2012 - Published in Biogeosciences Discuss.: 13 November 2012

Revised: 24 June 2013 - Accepted: 25 June 2013 - Published: 30 July 2013

\begin{abstract}
The northern latitudes are experiencing disproportionate warming relative to the mid-latitudes, and there is growing concern about feedbacks between this warming and methane production and release from high-latitude soils. Studies of methane emissions carried out in the Arctic, particularly those with measurements made outside the growing season, are underrepresented in the literature. Here we present results of $5 \mathrm{yr}$ (2006-2010) of automatic chamber measurements at a high-Arctic location in Zackenberg, NE Greenland, covering both the growing seasons and two months of the following freeze-in periods. The measurements show clear seasonal dynamics in methane emission. The start of the growing season and the increase in $\mathrm{CH}_{4}$ fluxes were strongly related to the date of snowmelt. Within each particular growing season, $\mathrm{CH}_{4}$ fluxes were highly correlated with the soil temperature $\left(R^{2}>0.75\right)$, which is probably explained by high seasonality of both variables, and weakly correlated with the water table. The greatest variability in fluxes between the study years was observed during the first part of the growing season. Somewhat surprisingly, this variability could not be explained by commonly known factors controlling methane emission, i.e. temperature and water table position. Late in the growing season $\mathrm{CH}_{4}$ emissions were found to be very similar between the study years (except the extremely dry 2010) despite large differences in climatic factors (temperature and water table). Late-season bursts of $\mathrm{CH}_{4}$ coinciding with soil freezing in the autumn were observed during at least three years. The cumulative emission during the freeze-in $\mathrm{CH}_{4}$ bursts was comparable in
\end{abstract}

size with the growing season emission for the year 2007, and about one third of the growing season emissions for the years 2009 and 2010. In all three cases the $\mathrm{CH}_{4}$ burst was accompanied by a corresponding episodic increase in $\mathrm{CO}_{2}$ emission, which can compose a significant contribution to the annual $\mathrm{CO}_{2}$ flux budget. The most probable mechanism of the late-season $\mathrm{CH}_{4}$ and $\mathrm{CO}_{2}$ bursts is physical release of gases accumulated in the soil during the growing season. In this study we discuss possible links between growing season and autumn fluxes. Multiannual dynamics of the subsurface $\mathrm{CH}_{4}$ storage pool are hypothesized to be such a link and an important driver of intearannual variations in the fluxes, capable of overruling the conventionally known short-term control factors (temperature and water table). Our findings suggest the importance of multiyear studies with a continued focus on shoulder seasons in Arctic ecosystems.

\section{Introduction}

The Arctic is changing as a consequence of climate change (Christensen et al., 2004; Johansson et al., 2006; Serreze et al., 2000; Tarnocai, 2006). Somewhere within all the changes that affect snow, ice, permafrost and vegetation distributions, a suite of changes to ecosystem biogeochemical cycling is also happening. With the effects of global warming becoming all the more evident and happening first in the Arctic, there is a special obligation to, first, monitor and study how the Arctic environment is changing and, 
second, improve our process-based understanding of how these changes are affecting and feeding back to the climate system (Callaghan et al., 2011).

There are several unresolved and also recently discovered new major questions regarding our basic understanding of the high northern latitudes and their greenhouse gas source strengths as well as the distribution of these in time and space (McGuire et al., 2012). Presently, we are lacking the capability to explain major variations in the growth rate of atmospheric methane. After a decade of unexplained variations (down to zero) in the growth rate of atmospheric $\mathrm{CH}_{4}$, the data from recent years show these concentrations are now increasing at a substantial rate. Evidence from the atmospheric $\mathrm{CH}_{4}$ and $\mathrm{CO}$ concentration as well as isotopic data indicates that there may well be a high-latitude biogenic source signature involved (E. J., Dlugokencky, personal communication, 2010). In general, these important oscillations in atmospheric methane concentrations are poorly understood, which highlights the need for long-term monitoring of source variations on the ground. Here we present a study of multiyear high time resolution observations of methane emissions from a high-Arctic site.

The main aims of our study were to

1. establish a system for automatic chamber monitoring of $\mathrm{CH}_{4}$ and $\mathrm{CO}_{2}$ fluxes in an Arctic fen (Zackenberg, NE Greenland) throughout the growing season and the following freeze-in period.

2. provide high time resolution $\mathrm{CH}_{4}$ flux measurements for a number of consecutive years $(5 \mathrm{yr}, 2006-2010$ in this study).

3. analyze the flux dynamics for each growing season; investigate the primary environmental controls on the $\mathrm{CH}_{4}$ emissions at a seasonal scale; and compare our findings with similar studies in the Arctic.

4. analyze the interannual variations in growing season fluxes; investigate possible controls of such variations; and compare our findings with similar studies in Arctic and boreal wetlands.

5. analyze the flux dynamics during freeze-in periods; investigate possible mechanisms of high autumn emissions; try to determine their controls; and compare our findings with existing data for autumn $\mathrm{CH}_{4}$ fluxes in the Arctic.

6. analyze possible interdependences between growing season fluxes and autumn bursts; and try to comprehend functioning of the local ecosystem in terms of $\mathrm{CH}_{4}$ exchange on a multiyear timescale.

\section{Methods}

\subsection{Site description}

Field measurements of $\mathrm{CH}_{4}$ and $\mathrm{CO}_{2}$ fluxes were carried out at a fen site in Zackenberg valley, situated in the Northeast Greenland National Park $\left(74^{\circ} 30^{\prime} \mathrm{N}, 21^{\circ} 00^{\prime} \mathrm{W}\right)$. The site is located in the high Arctic (Meltofte and Rasch, 2008), with monthly mean air temperatures below $-20^{\circ} \mathrm{C}$ during winter and between +3 and $+7{ }^{\circ} \mathrm{C}$ during summer (Hansen et al., 2008). Between 1991 and 2005 the area experienced a significant warming of $2.25^{\circ} \mathrm{C}$ (Hansen et al., 2008). The average annual precipitation was $261 \mathrm{~mm}$ for 1996-2005, with $90 \%$ as snow (Hansen et al., 2008). The site was established in 2005 within the GeoBasis part of the Greenland Ecosystem Monitoring (GEM) program. It is, however, very similar and close (within $50 \mathrm{~m}$ ) to an earlier flux measurement site (Joabsson and Christensen, 2001; Ström et al., 2003), and within $1000 \mathrm{~m}$ distance to the south of another former flux study site (Christensen et al., 2000; Friborg et al., 2000; Søgaard et al., 2000; Nordstrøm et al., 2001) and a current site making complimentary tower and experimental measurements (Tagesson et al., 2012), all in the same fen complex called Rylekcerene.

The current site vegetation was dominated by Eriophorum scheuchzeri, Carex stans and Dupontia psilosantha. The dominating moss genera at the site were Tomenthypnum, Scorpidium, Aulacomnium and Drepanoclaudus.

\subsection{Measurements and calculations}

Fluxes of $\mathrm{CH}_{4}$ and $\mathrm{CO}_{2}$ were measured using an automatic chamber technique (Goulden and Crill, 1997). Six transparent Plexiglas chambers $0.6 \mathrm{~m} \times 0.6 \mathrm{~m}$ in area and $0.3 \mathrm{~m}$ in height were installed along a transect from the fringe of the fen into the wet fen area. The distance between individual chambers was $0.3-0.6 \mathrm{~m}$. Each chamber was equipped with a fan for ventilation and gas mixing. The chambers were connected to a stationary analytical box by couples of $25 \mathrm{~m}$-long high-density polyethylene tubes (inner diameter $4 \mathrm{~mm}$ ). Each chamber was activated for 10 min every hour; the gas from the active chamber was pumped at a rate of approximately $0.4 \mathrm{~L} \mathrm{~min}^{-1}$ through a nondestructive $\mathrm{CO}_{2}$ analyzer (SBA4, PP Systems, UK) and a likewise nondestructive $\mathrm{CH}_{4}$ analyzer (DLT100, Los Gatos Research, USA) before returning to the chamber. The primary concentration data were recorded at $1 \mathrm{~Hz}$ for $\mathrm{CH}_{4}$ and $0.625 \mathrm{~Hz}$ for $\mathrm{CO}_{2}$. The active chamber fan was running all 10 minutes; the first $3 \mathrm{~min}$ the chamber was ventilated open, then closed for $5 \mathrm{~min}$, then opened again and ventilated for $2 \mathrm{~min}$.

The chambers were installed in August 2005. Due to possible artificial effects of installations, however, the data from 2005 are not included in the current study. Due to various technical problems, the data stream each year contained more-or-less prolonged gaps. In 2006 the measurements 
started before snowmelt and ended 26 August 2006 eleven days before the estimated end of the growing season, which followed from the routine closing of the Zackenberg station as practiced until 2007. In 2006 the measurements had many small interruptions, caused by power supply instability (generator failures); moreover, only four out of six chambers were working this season (the remaining two were destroyed by muskoxen). The snowmelt in 2007 was almost a month earlier than in 2006, and the measurements only commenced 14 days after the snowmelt. As part of the International Polar Year it was decided to keep operations of Zackenberg Research Station two months longer than usual in 2007. This practice has been carried out since then, keeping the station open until late October with $\mathrm{CH}_{4}$ measurements being continued as long into the autumn as possible. During 2008 the automatic system was working well and almost without interruptions from the second day after snowmelt until day of year (DOY) 238, when surface water was accidentally soaked into the instrument and its cell was stained. However, for a period of DOY 283-290 another $\mathrm{CH}_{4}$ analyzer (DLT200, Los Gatos Research, USA) was borrowed and connected to the automatic chamber 1 , working in its normal schedule (one measurement per hour). During 2009 the system was started one week after the snowmelt and worked well until DOY 193, when, due to technical problems (the laser wore out and the instrument had to be sent for repair), measurements were interrupted until DOY 224. During the gap, three campaigns of semi-manual measurements were performed at DOY 208, 212 and 217 (with an analyzer borrowed from a separate study). The regular measurements resumed at DOY 224 and continued until DOY 297. During 2010 the system was started one week after the snowmelt and worked well until DOY 306 (further extended measurement campaign). The continuity in the $\mathrm{CO}_{2}$ and $\mathrm{CH}_{4}$ measurements were closely linked during all five years, so the timing and source of most data gaps were the same, except for 2006, when the $\mathrm{CO}_{2}$ analyzer broke down on DOY 219, while the $\mathrm{CH}_{4}$ analyzer was working until DOY 238.

$\mathrm{CH}_{4}$ and $\mathrm{CO}_{2}$ fluxes were calculated upon the linear regression over the primary concentration data (for the detailed description of calculation methods, see Mastepanov et al., 2013) using air temperature and pressure data collected at a meteorological station (ClimateBasis, 2010; Hansen et al., 2008) about $700 \mathrm{~m}$ from the site. For ebullition different calculation methods were used, based on bubble frequency and mean $\mathrm{CH}_{4}$ and $\mathrm{CO}_{2}$ content.

For an interannual comparison of the environmental parameters and flux time series, most of which had gaps in the data or slightly different ways of being measured, a ranking was used. We used either integration of regular gapless measurements (air and soil temperatures) or a visual integration for irregular measurements (water table level, soil thaw depth) and data with gaps $\left(\mathrm{CH}_{4}\right.$ and $\mathrm{CO}_{2}$ fluxes). The ranking was done between years within three 30-day intervals. Highest values were represented as rank 1, followed by rank
2 , etc. When the difference between two or more years was much smaller than between others, their rank was considered the same.

In addition to $\mathrm{CO}_{2}$ and $\mathrm{CH}_{4}$, the ambient PAR (Photosynthetically active radiation) level was measured at $10 \mathrm{~Hz}$ and recorded as $1 \mathrm{~Hz}$ averages using one sensor (LI-190SA, LiCor, USA) installed outside the chambers. The soil temperatures at 5,10 and $15 \mathrm{~cm}$ depths were recorded near the middle of the chamber transect by loggers (Tinytag Plus, Gemini Data Loggers, UK), every 5 min during June-October and every one hour during the rest of the year. Water table depth and soil thaw depth were measured manually every one-two weeks in the snow-free season. In 2006 the water table and the soil thaw were measured in a single representative location at the site, relative to the surface of mosses. In 2007 a reference one-meter metal stick was hammered down to the permafrost; then the surface, water table and soil thaw levels were measured relative to the stick zero mark (which was at the moss surface level when installed), in 6 locations in front of each chamber. Once per year this zero mark was checked by differential GPS.

\subsection{Timescale definitions}

For the data treatment and representation we used the following timescale definitions:

DOY: widely used timescale representation relative to the start of calendar year. In our calculations 1 January was DOY 1 and 2 January was DOY 2, etc., in integer representation. In fractional representation 1 January 06:00 was DOY 1.25 and 1 January 18:00 was DOY 1.75, etc.

Day after snowmelt (DASM): suggested timescale representation relative to the start of the growing season. Zero on this scale is the date, or DOY, when the snow cover in the chambers and around the chambers disappeared. In some years it can have \pm 1 day precision due to the arbitrary determination. This day was regarded as DASM 0 in our calculations when integer representation was used; the next day was regarded as DASM 1, etc. When fractional representation was needed, 00:00 of this zero day was regarded as DASM 0.00 (and e.g. 06:00 as DASM 0.25), although the time of the complete snowmelt was observed a few hours later.

Growing season: defined as the interval between DASM 0 and the date when soil at $5 \mathrm{~cm}$ depth reached $0^{\circ} \mathrm{C}$ again.

Zero curtain period: time interval clearly visible in soil temperature records when the temperature stays close to zero (because of water-ice phase change) - in our case defined between the first day after the growing season and the date when the soil temperature at $5 \mathrm{~cm}$ started to fall below zero, with $<1{ }^{\circ} \mathrm{C}$ precision.

Freezing period: the interval between the end of zero curtain period and the moment when the entire active layer is frozen. Due to closure of the station our measurements never 
Table 1. Timing, temperature and flux values for five seasons, 2006-2010.

\begin{tabular}{|c|c|c|c|c|c|c|}
\hline & & 2006 & 2007 & 2008 & 2009 & 2010 \\
\hline \multicolumn{7}{|c|}{ Key dates } \\
\hline \multirow{2}{*}{ Snowmelt } & date & $5 \mathrm{Jul}$ & 12 Jun & 23 Jun & 1 Jun & 16 Jun \\
\hline & DOY & 186 & 163 & 175 & 152 & 167 \\
\hline \multirow{2}{*}{$=0{ }^{\circ} \mathrm{C}$ at $-5 \mathrm{~cm}$} & date & $6 \mathrm{Sept}$ & $7 \mathrm{Sept}$ & 24 Sept & $7 \mathrm{Sept}$ & 19 Sept \\
\hline & DOY & $249^{a}$ & 250 & 268 & 250 & 262 \\
\hline \multirow{2}{*}{$<0{ }^{\circ} \mathrm{C}$ at $-5 \mathrm{~cm}$} & date & 23 Sept & 24 Sept & 10 Oct & 4 Oct & 4 Oct \\
\hline & DOY & $266^{\mathrm{a}}$ & 267 & 284 & 277 & 277 \\
\hline \multirow{2}{*}{$<0^{\circ} \mathrm{C}$ at $-15 \mathrm{~cm}$} & Date & - & 7 Oct & 19 Oct & 24 Oct & 18 Oct \\
\hline & DOY & - & 280 & 293 & 297 & 291 \\
\hline \multicolumn{2}{|c|}{ Growing season (days) } & 63 & 87 & 93 & 98 & 95 \\
\hline \multicolumn{2}{|c|}{ Zero curtain period (days) } & 17 & 17 & 16 & 27 & 15 \\
\hline \multicolumn{2}{|c|}{ Freezing $5-15 \mathrm{~cm}$ (days) $^{\mathrm{b}}$} & - & 13 & 9 & 20 & 14 \\
\hline \multicolumn{7}{|c|}{ Average air temperature $\left({ }^{\circ} \mathrm{C}\right)$} \\
\hline \multirow{2}{*}{ Jun } & absolute & 1.03 & 3.31 & 4.98 & 1.76 & 2.25 \\
\hline & $\Delta 10^{\mathrm{c}}$ & -1.02 & +1.26 & +2.93 & -0.29 & +0.20 \\
\hline & absolute & 6.62 & 5.88 & 8.82 & 8.22 & 5.61 \\
\hline & $\Delta 10^{\mathrm{c}}$ & +0.81 & +0.07 & +3.01 & +2.41 & -0.20 \\
\hline \multirow{2}{*}{ Aug } & absolute & 5.51 & 6.60 & 6.93 & 4.95 & 6.48 \\
\hline & $\Delta 10^{\mathrm{c}}$ & +0.67 & +1.76 & +2.09 & +0.11 & +1.64 \\
\hline \multicolumn{2}{|l|}{ Jun-Jul-Aug } & 4.43 & 5.28 & 6.93 & 5.01 & 4.80 \\
\hline \multicolumn{2}{|l|}{ Growing season } & 5.69 & 5.32 & 6.27 & 4.89 & 5.16 \\
\hline \multicolumn{2}{|c|}{ First 40 days of growing season } & 7.13 & 5.42 & 7.68 & 1.76 & 4.49 \\
\hline \multicolumn{7}{|c|}{ Growing season fluxes } \\
\hline \multicolumn{2}{|c|}{$\mathrm{CH}_{4}$ average $\left(\mathrm{mgCH}_{4} \mathrm{~m}^{-2} \mathrm{~h}^{-1}\right)$} & 2.36 & 2.61 & 0.85 & 1.21 & 0.87 \\
\hline \multicolumn{2}{|c|}{$\mathrm{CH}_{4}$ total $\left(\mathrm{g} \mathrm{Cm}^{-2}\right)$} & 2.68 & 4.09 & 1.42 & 2.13 & 1.49 \\
\hline \multicolumn{2}{|c|}{$\mathrm{CH}_{4}$ peak $^{\mathrm{d}}\left(\mathrm{mgCH}_{4} \mathrm{~m}^{-2} \mathrm{~h}^{-1}\right)$} & 4.6 & 6.5 & 1.8 & 2.2 & 2.6 \\
\hline \multicolumn{2}{|c|}{$\mathrm{CO}_{2}$ average $\left(\mathrm{mgCO}_{2} \mathrm{~m}^{-2} \mathrm{~h}^{-1}\right)$} & -92.7 & -130.9 & -316.9 & -58.9 & -58.7 \\
\hline \multicolumn{2}{|c|}{$\mathrm{CO}_{2}$ total $\left(\mathrm{g} \mathrm{Cm}^{-2}\right)$} & -38.2 & -74.5 & -192.5 & -37.8 & -36.5 \\
\hline \multicolumn{7}{|c|}{ Post-growing season fluxes } \\
\hline \multicolumn{2}{|c|}{$\mathrm{CH}_{4}$ average $^{\mathrm{e}}\left(\mathrm{mgCH}_{4} \mathrm{~m}^{-2} \mathrm{~h}^{-1}\right)$} & - & 4.26 & 0.11 & 0.92 & 0.55 \\
\hline \multicolumn{2}{|c|}{$\mathrm{CH}_{4}$ total, $\quad \mathrm{gC}^{-2}$} & - & 3.76 & 0.02 & 0.80 & 0.44 \\
\hline \multicolumn{2}{|c|}{ at least $\quad \%$ of $\mathrm{GS}^{\mathrm{f}}$} & - & $92 \%$ & $1 \%$ & $37 \%$ & $30 \%$ \\
\hline \multicolumn{2}{|c|}{$\mathrm{CO}_{2}$ average $^{\mathrm{e}}\left(\mathrm{mgCO}_{2} \mathrm{~m}^{-2} \mathrm{~h}^{-1}\right)$} & - & 405.3 & - & 151.3 & 336.9 \\
\hline \multirow{2}{*}{\multicolumn{2}{|c|}{$\begin{array}{l}\mathrm{CO}_{2} \text { total, } \quad \mathrm{gCm}^{-2} \\
\text { at least } \quad \% \text { of GS }\end{array}$}} & - & 130.0 & - & 8.9 & 99.2 \\
\hline & & - & $-174 \%$ & - & $-24 \%$ & $-272 \%$ \\
\hline
\end{tabular}

a Temperature data from the main climate station. ${ }^{\mathrm{b}}$ This interval is not equal to freezing period as it was defined in chapter 2.3 but is a characteristic of soil freezing rate.

${ }^{c}$ Average for the corresponding year minus average for previous $10 \mathrm{yr}, 1996-2005 .{ }^{\mathrm{d}}$ Maximal daily average within the growing season. ${ }^{\mathrm{e}}$ For days when valid

measurements exist. ${ }^{f}$ Growing season.

continued until the end of the freezing period since that occurs later during the winter.

Post-growing season: the interval from the start of zero curtain period to the end of the measurement campaign.

\section{Results}

\subsection{Environmental conditions}

A summary of air temperature and key dates related to the temperature regimes for the years 2006-2010 is presented in Table 1. The growing seasons for the different years were very different with respect to the start and end dates, as well as in the zero curtain period timing and length. The maximum variation between snowmelt dates reached 34 days between the earliest (2009) and the latest (2006) during the 
Table 2. Ranking of 2006-2010 growing seasons in environmental conditions, $\mathrm{CO}_{2}$ and $\mathrm{CH}_{4}$ fluxes. Rank 1 means highest values, similar ranks mean close values.

\begin{tabular}{|c|c|c|c|c|c|c|}
\hline Parameter & Interval, DASM & 2006 & 2007 & 2008 & 2009 & 2010 \\
\hline \multirow[t]{3}{*}{ Air temperature } & $0-30$ & 2 & 3 & 1 & 5 & 4 \\
\hline & $30-60$ & 5 & 4 & 1 & 2 & 3 \\
\hline & 60-90 & 5 & 2 & 3 & 1 & 4 \\
\hline \multirow[t]{3}{*}{ Soil temperature } & $0-30$ & - & - & 1 & 3 & 2 \\
\hline & $30-60$ & - & 3 & 1 & 2 & 4 \\
\hline & 60-90 & - & 2 & 2 & 1 & 2 \\
\hline \multirow[t]{3}{*}{ Water table level } & $0-30$ & 1 & 2 & 3 & 3 & 4 \\
\hline & $30-60$ & 1 & 3 & 2 & 3 & 4 \\
\hline & 60-90 & - & 3 & 1 & 2 & 4 \\
\hline Active layer & $0-30$ & 3 & 1 & 2 & 1 & 2 \\
\hline \multirow[t]{2}{*}{ thickness } & $30-60$ & 3 & 1 & 4 & 2 & 3 \\
\hline & 60-90 & - & 1 & 3 & 4 & 2 \\
\hline \multirow[t]{3}{*}{ Net $\mathrm{CO}_{2}$ fixation } & $0-30$ & 4 & 2 & 1 & 5 & 3 \\
\hline & $30-60$ & - & 2 & 1 & 2 & 2 \\
\hline & 60-90 & - & 1 & - & 1 & 2 \\
\hline \multirow[t]{3}{*}{ Net $\mathrm{CH}_{4}$ emission } & $0-30$ & 2 & 1 & 5 & 4 & 3 \\
\hline & $30-60$ & 1 & 2 & 3 & 3 & 4 \\
\hline & $60-90$ & - & 1 & - & 1 & 2 \\
\hline
\end{tabular}

study years. Consequently, the duration of the growing season in 2009 was about $1 / 3$ longer than in 2006. However, the growing season ending date did also vary up to 19 days (between 2006 and 2008).

The monthly average air temperatures for June, July and August were in most cases higher than for the previous tenyear period, except for a colder June in 2006 and 2009 and July in 2010. The warmest year of the five was 2008, for the three summer months individually, for the average of these three months and for the growing season average. The nominally coldest JJA average temperature was 2006; however, 2009 had a lower growing season average (Table 1).

The soil temperature records at the site were started in late June 2007. The subsequent dynamics are shown in Fig. 1, both on DOY and DASM scale. For interannual comparison of soil temperatures, ranking was used (Table 2). For the first and second 30 days of the growing season, 2008 was warmest; for the third 30 days, 2009 was warmer. In the end of the growing seasons, the temperatures at all 3 depths came to $0^{\circ} \mathrm{C}$, and then stayed almost constant for $2-3$ weeks (i.e. the zero curtain period; see Table 1 ). The zero curtain periods had practically the same duration in four out of five years, except almost $60 \%$ longer in 2009 because of unusually early and deep snow cover, insulating the soil. The following freezing of the active layer was also slower in 2009.

The water table dynamics in 2006-2010 are shown in Fig. 2 with ranks in Table 2. After snowmelt, the water ta- ble was above the surface (here defined as the average surface of moss layer) in 2006-2007, and close to the surface in 2008-2010. We have no measurements of water movement, but we could visually observe that the water regime at the site changed between 2007 and 2008 seasons. Surface water was moving slowly in 2006-2007, but much faster in 2008-2010. During the growing season the water table was generally decreasing (Fig. 2); however, large variations due to precipitation were observed. In 2010 the water table was lower than in any other year during the whole growing season.

The dynamics of soil thaw depth (the distance between the moss surface and the table of the frozen layer) are shown in Fig. 3a, b. The soil started to thaw about the date of snowmelt; however, the initial rate of thawing was different in different years. The maximum active layer thickness was found in 2009 (Fig. 3a, b); however, the measurements of the freezing front relative to the fix point (Fig. 3c) showed that the permafrost table was moving deeper every year during 2006-2009, but the surface was also lowered. In 2010, the absolute position of the permafrost table did not change, but the active layer became significantly thinner toward the end of the growing season because of the lowering surface.

\section{2 $\mathrm{CH}_{4}$ fluxes}

The dynamics of $\mathrm{CH}_{4}$ fluxes for 2006-2010 are shown in Fig. 4, with the main summarizing values included in Table 1. 


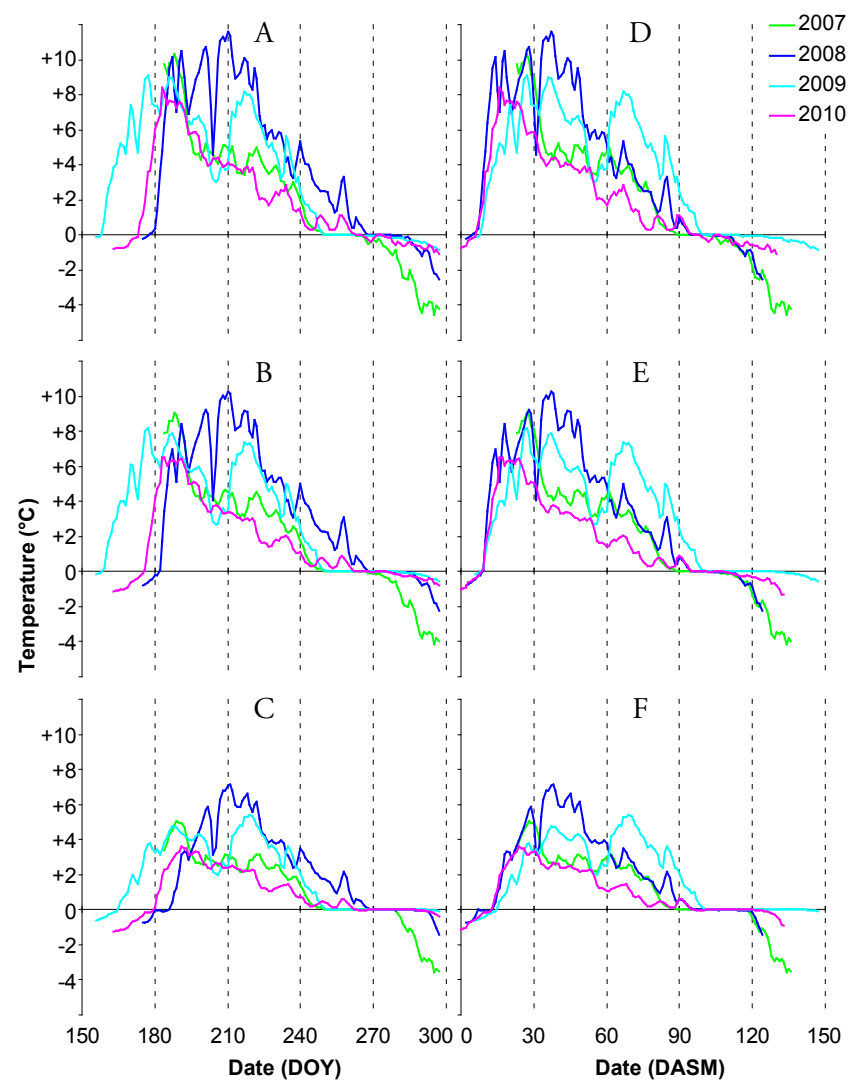

Fig. 1. Soil temperature dynamics at 3 depths. A, D $5 \mathrm{~cm} ; \mathbf{B}, \mathbf{E}$ $10 \mathrm{~cm} ; \mathbf{C}, \mathbf{F} 15 \mathrm{~cm}$ depth. A, B, C normalized to day of year (DOY); D, E, F normalized to day after snowmelt (DASM).

In 2006 we observed $\mathrm{CH}_{4}$ fluxes starting a few days after snowmelt and exponentially increasing until DASM 21 . Then the fluxes stabilized for about a week and started to gradually decrease.

During 2007, the first week of measurements gave results very similar to 2006 (in DASM timescale, Fig. 4b), then the flux continued to rise above 2006 level, and only about DASM 30 started to decline. It gradually decreased during the rest of the growing season and through the zero curtain period. Quite unexpectedly, after the zero curtain period, the fluxes started to increase again and peaked with extremely high values up to $112.5 \mathrm{mg} \mathrm{CH}_{4} \mathrm{~m}^{-2} \mathrm{~h}^{-1}$ (Mastepanov et al., 2008). The maximum of this late-season emission peak was observed around DOY 280; however, the measurements did not continue long enough to document the end of the peak, allowing only a partial estimate of the total amount of emitted methane. The registered amount of $\mathrm{CH}_{4}$ emitted during post-growing season 2007 was $3.76 \mathrm{~g} \mathrm{C} \mathrm{m}^{-2}$, or about $92 \%$ of the estimated growing season emission (Table 1).

During 2008, $\mathrm{CH}_{4}$ emissions were extremely low until DASM 17 (Fig. 4), then started to slowly rise until DASM 45-49, when it more or less reached the level of the same relative period in 2006 and 2007. Then the emission declined
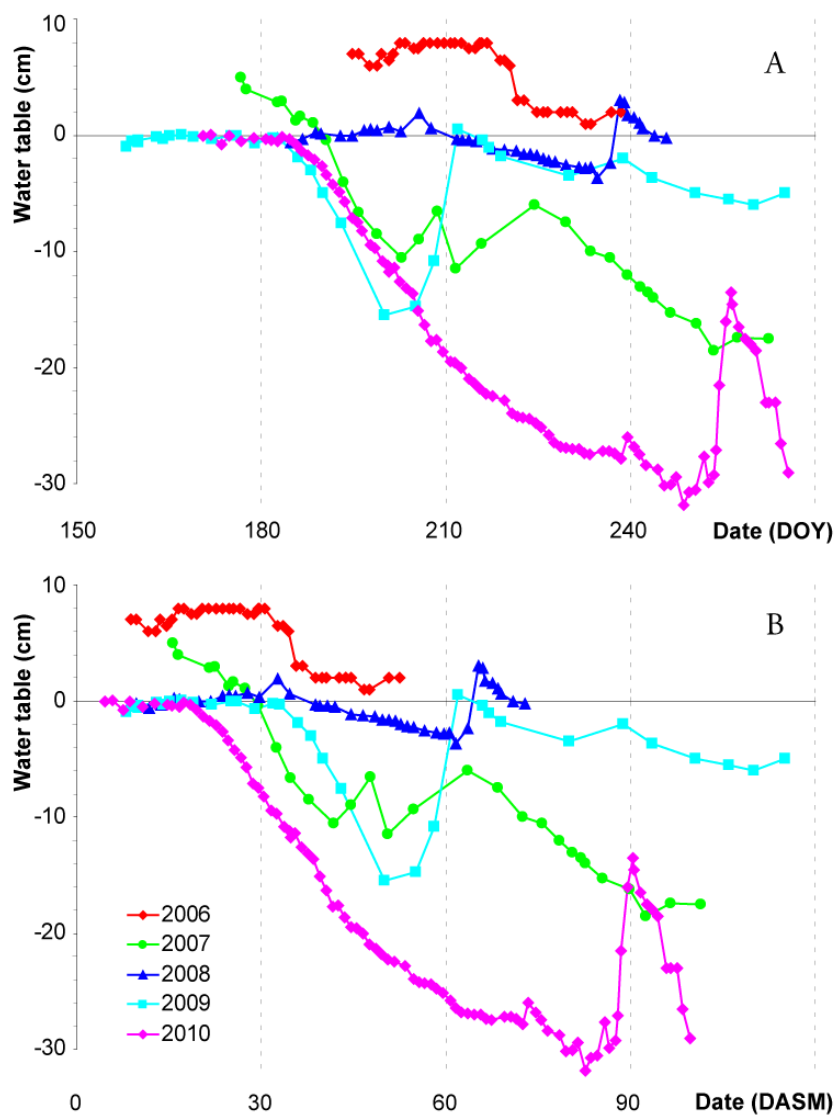

Fig. 2. Water table level dynamics. A normalized to day of year (DOY); B normalized to day after snowmelt (DASM).

like in 2007. The measurements during the freeze in period (DOY 283-290) showed very low fluxes (Fig. 4a) with no evidence of the late-season peak.

During 2009 the rates of $\mathrm{CH}_{4}$ emission increased during the first 30 days of the growing season and were intermediate between 2008 and 2006-2007; then the fluxes started to decrease and came in level with the preceding years. The first signs of late-season emission peak were registered at DOY 263; however, the following fluxes were not as high as in 2007. Only three days of very high fluxes (up to $99 \mathrm{mg}$ $\mathrm{CH}_{4} \mathrm{~m}^{-2} \mathrm{~h}^{-1}$ ) were registered in one of the chambers at DOY 293-295, while the average post-growing season flux for all 6 chambers was $0.92 \mathrm{mg} \mathrm{CH}_{4} \mathrm{~m}^{-2} \mathrm{~h}^{-1}$ (Table 1), more than 4 times less than in 2007.

In the beginning of the growing season of $2010, \mathrm{CH}_{4}$ fluxes rapidly increased, then stopped around DASM 20 and thereafter gradually decreased. Thus the maximum of the emission peak was higher and earlier than in 2008 and 2009 (Fig. 4b) although lower and earlier than in 2006 and 2007. The emission rates in the second half of the growing season 2010 were significantly lower than in 2006-2009. During the freezing season 2010 a limited but significant increase in $\mathrm{CH}_{4}$ emission was detected (Fig. 4a). The average 

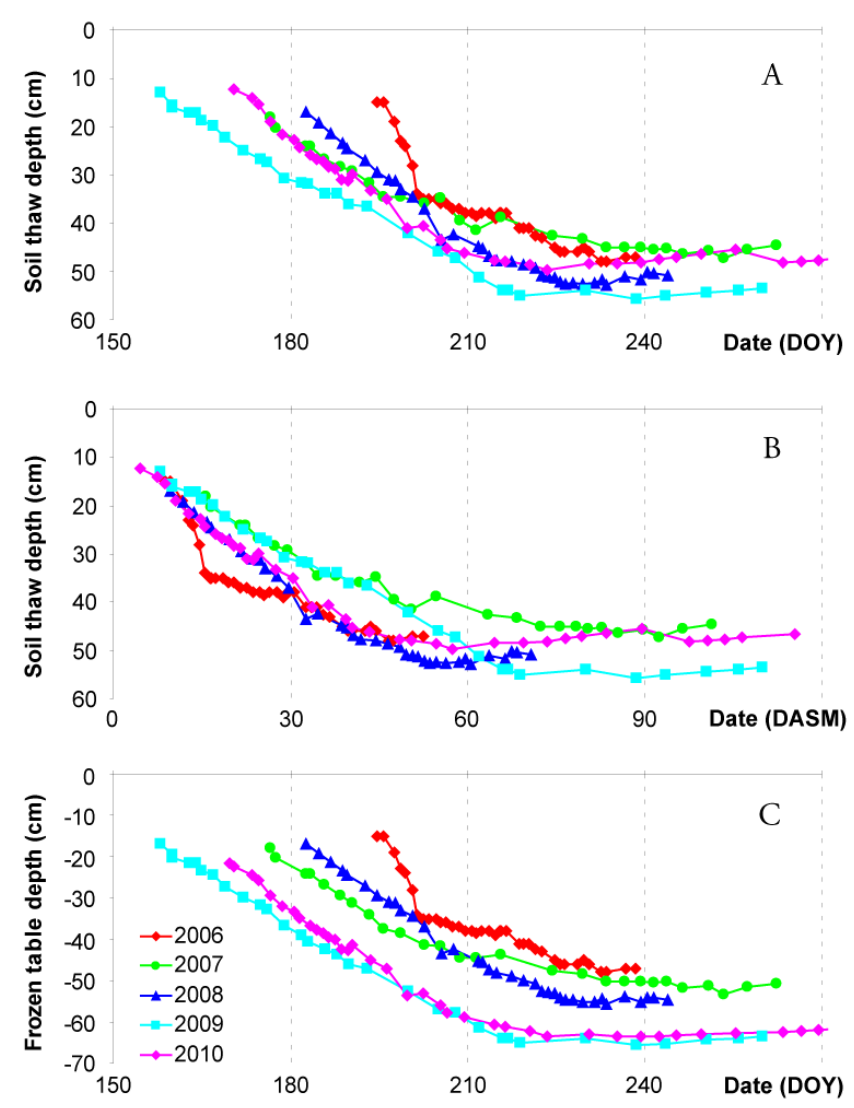

Fig. 3. Soil thaw dynamics. A, B soil thaw depth (relative to the surface); $\mathbf{C}$ frozen table depth relative to the reference level. $\mathbf{A}, \mathbf{C}$ normalized to day of year (DOY); B normalized to day after snowmelt (DASM).

post-growing season flux was $0.55 \mathrm{mg} \mathrm{CH}_{4} \mathrm{~m}^{-2} \mathrm{~h}^{-1}$, with the total registered amount equaling $30 \%$ of the growing season $\mathrm{CH}_{4}$ (Table 1).

Diurnal variations in $\mathrm{CH}_{4}$ fluxes were found in the beginning and in the end of a growing season, but not during the peak (see Supplement).

\section{$3.3 \mathrm{CO}_{2}$ fluxes}

The dynamics of $\mathrm{CO}_{2}$ fluxes for 2006-2010 are shown in Fig. 5, with the main numbers included in Table 1 . The growing season $\mathrm{CO}_{2}$ fluxes (NEE) were more variable than $\mathrm{CH}_{4}$ emissions. At the start of the season, i.e. the first 7-12 days after snow melt, the ecosystem was a small atmospheric source of $\mathrm{CO}_{2}$. Afterwards $\mathrm{CO}_{2}$ fixation started to prevail. During the first 30 days of the growing season the most pronounced net carbon uptake was registered in 2007 and 2008, with the 2008 uptake lasting longer and with a greater strength (daily average of $-211 \mathrm{mg} \mathrm{C} \mathrm{m}^{-2} \mathrm{~h}^{-1}$ ), while in 2007 the uptake was shorter and weaker. After the peak, the ecosystem production started to decrease. NEE crossed zero around DOY 230-240. The first 30 days of the growing sea-
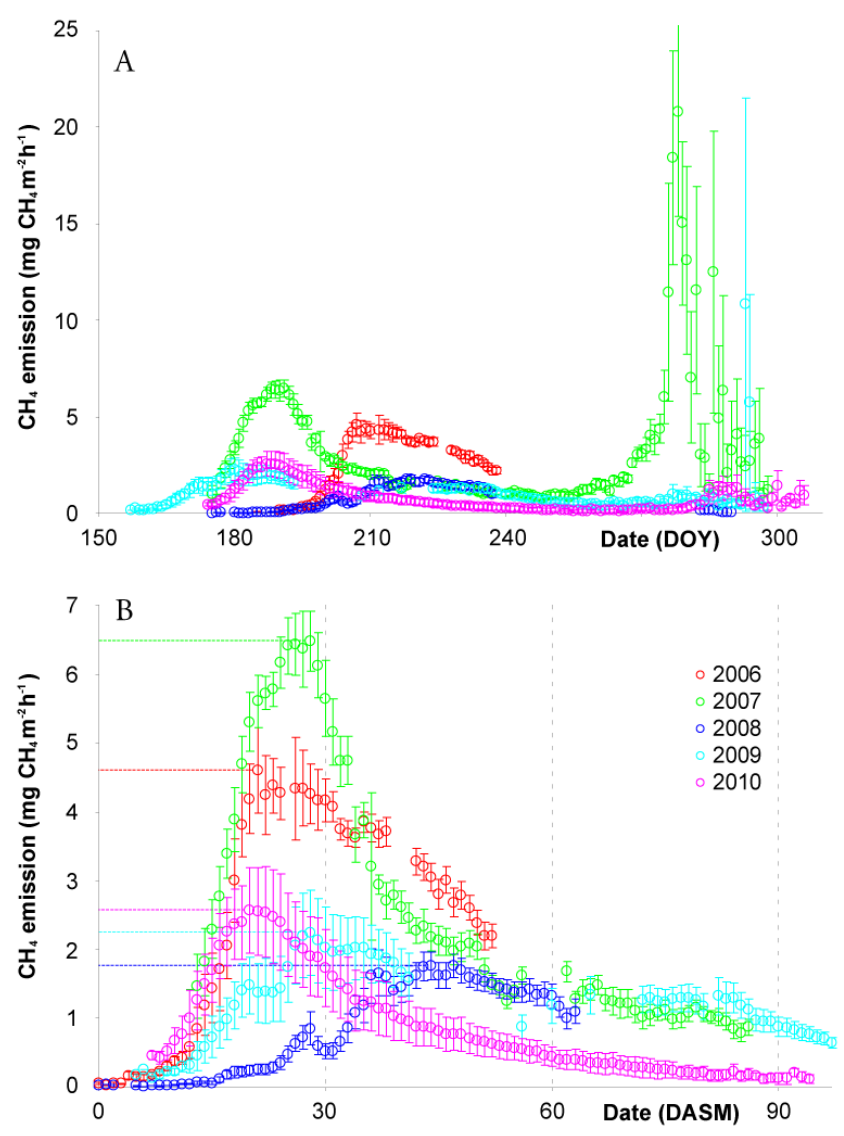

Fig. 4. $\mathrm{CH}_{4}$ emission dynamics. A all measured fluxes, normalized to day of year (DOY); B growing season fluxes, normalized to day after snow melt (DASM). Each circle states the average between daily averaged hourly measurements of 6 or less individual chambers; error bars state the standard error between daily average values of individual chambers.

son in 2009 were significantly less productive (lowest daily average NEE of $-66 \mathrm{mg} \mathrm{Cm}^{-2} \mathrm{~h}^{-1}$ ), with the later seasonal dynamics being uncertain due to measurement gaps. The productivity during the first 30 days of growing season 2006 were somewhere between 2007-2008 and 2009, with the later seasonal dynamics in 2006 being somewhat uncertain. In $2010 \mathrm{CO}_{2}$ fluxes were close to 2007-2008 values during DASM 20-30 but then changed to less fixation and even net emission.

In the post-growing season 2007 (starting from DOY 263) a $\mathrm{CO}_{2}$ emission peak was observed; the highest flux values reached $3 \mathrm{~g} \mathrm{CO}_{2} \mathrm{~m}^{-2} \mathrm{~h}^{-1}$, while the average for all registered post-growing season $\mathrm{CO}_{2}$ fluxes was about $400 \mathrm{mg}$ $\mathrm{CO}_{2} \mathrm{~m}^{-2} \mathrm{~h}^{-1}$ (Table 1). As for $\mathrm{CH}_{4}$, the $\mathrm{CO}_{2}$ measurements also did not continue long enough to capture the end of the peak and measure the whole amount of emitted $\mathrm{CO}_{2}$. The registered amount of $\mathrm{CO}_{2}$ emitted during post-growing season 2007 was $130 \mathrm{~g} \mathrm{C} \mathrm{m}^{-2}$, almost two times more than was taken up during the growing season (Table 1). In the late 


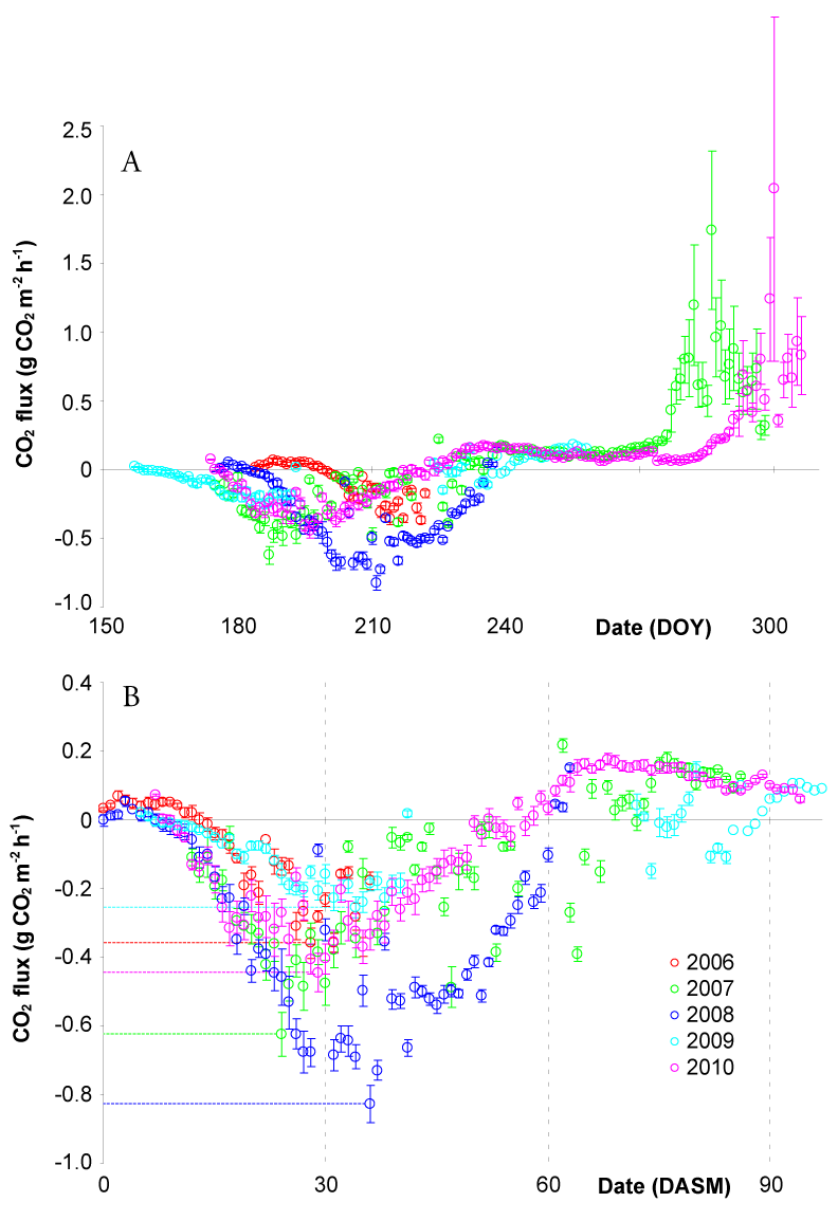

Fig. 5. $\mathrm{CO}_{2}$ flux dynamics. A all measured fluxes, normalized to day of year (DOY); B growing season fluxes, normalized to day after snow melt (DASM). Each circle states the average between daily averaged hourly measurements of 6 or less individual chambers; error bars state the standard error between daily average values of individual chambers.

season 2009 only moderate fluxes were observed - the highest flux value reaching $242 \mathrm{mg} \mathrm{CO}_{2} \mathrm{~m}^{-2} \mathrm{~h}^{-1}$, while the average for all registered post-growing season $\mathrm{CO}_{2}$ fluxes was about $150 \mathrm{mg} \mathrm{CO}_{2} \mathrm{~m}^{-2} \mathrm{~h}^{-1}$. The registered amount of $\mathrm{CO}_{2}$ emitted during post-growing season 2009 was $8.9 \mathrm{~g} \mathrm{C} \mathrm{m}^{-2}$, or about a quarter of the carbon that was taken up during the growing season (Table 1). In the post-growing season 2010 a strong $\mathrm{CO}_{2}$ emission was observed. The highest flux values were more than $10 \mathrm{~g} \mathrm{CO}_{2} \mathrm{~m}^{-2} \mathrm{~h}^{-1}$, while the average for all registered post-growing season $\mathrm{CO}_{2}$ fluxes was about $340 \mathrm{mg} \mathrm{CO} \mathrm{m}^{-2} \mathrm{~h}^{-1}$ (Table 1). The registered amount of $\mathrm{CO}_{2}$ emitted during post-growing season 2010 was almost $100 \mathrm{~g} \mathrm{C} \mathrm{m}^{-2}$, or almost three times more than was taken up during the growing season.

\subsection{Ebullition}

All the fluxes described above are so-called steady fluxes (Ström et al., 2005). The events of rapid concentration changes were observed on the order of 10 per month per chamber, but most of them could not be clearly defined as ebullition. For defined cases the typical amounts of $\mathrm{CH}_{4}$ and $\mathrm{CO}_{2}$ released by a single bubble were on the order of $0.1 \mathrm{mg}$ of $\mathrm{CH}_{4}$ and $1 \mathrm{mg}$ of $\mathrm{CO}_{2}$, respectively. The estimated seasonal ebullitional release of both $\mathrm{CH}_{4}$ and $\mathrm{CO}_{2}$ were within $0.1-1 \%$ of the total seasonal flux. As this value appeared to be within the uncertainty in the steady fluxes, the ebullition events were neglected in all the following calculations and discussions.

\section{Discussion}

\subsection{Growing season}

\subsubsection{Environmental variables}

In the literature, there are different ways to define the growing season depending on the focus of study (e.g. Grøndahl et al., 2007, 2008; Jackowicz-Korczynski et al., 2010). In this study we need a timescale that would help to compare the different years, highlighting the similarities and the differences between them. The most straight-forward, calendar-based timescale does not work for an ecosystem, where snowmelt, thawing of the soil, vegetation development, as well as $\mathrm{CH}_{4}$ and $\mathrm{CO}_{2}$ fluxes may be shifted more than a month at the beginning of the season (see Table 1 and Figs. 1, 3, 4, 5). However, taking the snowmelt date as the starting point of the growing season (Grøndahl et al., 2007) proved a useful unifying concept for the majority of environmental factors and for $\mathrm{CH}_{4}$ and $\mathrm{CO}_{2}$ fluxes. Not only is snowmelt itself important, but it also triggers a strong energy flux into the soil and thawing of the soil. In Zackenberg snow thaws rapidly, and the date when the upper $5-10 \mathrm{~cm}$ of the soil reach positive temperatures is within 1-2 days from the date of visual snowmelt, both in dry and wet subhabitats. In this context it does not really matter whether we define day zero as the first snow-free day or as the first day when the soil temperature at $5-10 \mathrm{~cm}$ went above zero. As we have longer visual records of snowmelt at our site, we have chosen the former.

As our main focus in this study was on $\mathrm{CH}_{4}$ fluxes, and the most intriguing finding was the late-season $\mathrm{CH}_{4}$ burst during gradual freezing of the active layer (Mastepanov et al., 2008), we chose the soil temperature as the main proxy for the end of the growing season. At DOY 250-270 (Fig. 1) the soil temperature at 5,10 and $15 \mathrm{~cm}$ came to zero almost synchronously, and then kept steady during the zero curtain period, when the free water in the soil profile was gradually turning to ice. During this period in 2007, 2009 and 2010 the increase in $\mathrm{CH}_{4}$ fluxes started. When the soil temperature at any sensor fell below zero, we concluded that all free water 
at this layer was frozen and the frozen front was gradually moving down. We used the time it took the freezing front to move from 5 to $15 \mathrm{~cm}$ depth as a proxy of the freezing speed (Table 1).

Snow and snowmelt are one of the main controlling factors for the beginning of the growing season (Grøndahl et al., 2008). A greater amount of snow, causing a later snowmelt, also leads to a larger amount of water inputs to the soils afterwards. Indeed, after a very late snowmelt in 2006 the water at the site was standing high for the subsequent 30 days; in 2007 the snow melted much earlier, and the water table dropped faster (Fig. 2). However, this situation was different in 2008-2010: during the first 30 days the water table stayed constantly near the surface, regardless of a very different snowmelt date and precipitation pattern (not shown). This may be an indication of a changed water regime, from more stagnant system in 2006-2007 to a more running one in 2008-2010. After the DASM 30 the water table dynamics were very variable in the five years and in this latter part of the season mainly reflecting variations in the precipitation pattern.

The dynamics of the soil thaw are an important factor both for seasonal and for interannual subsurface processes. The majority of $\mathrm{CH}_{4}$ and $\mathrm{CO}_{2}$ emitted at the surface originate from processes taking place in unfrozen soil. Both $\mathrm{CO}_{2}$ and $\mathrm{CH}_{4}$ production at temperatures below zero have been documented (e.g. Rivkina et al., 2000; Panikov et al., 2006), but their magnitude is dismissible compared with abovezero-degree production rates. If permafrost thawing is taking place, new layers are included in the active turnover every year, which can have significant effects on the ecosystem's carbon budget in a setting where the permafrost is rich in organic matter (e.g. Zimov et al., 2006; Schuur et al., 2009). Lowering of the permafrost table is not equal to increasing of active layer thickness in the case of the surface subsidence (surface settlement - Tarnocai et al., 2004). Since installing a permanent reference point in 2007 we observed vertical movements of the soil and moss surface both at seasonal and multiyear timescale. Within a season these movements were probably caused by water level (at high water peat and vegetation slightly expand upwards, while at low water the matrix collapses) and freezing/melting (water-filled matrix expands when freezing and collapses when melting). Thus, towards the end of the growing season 2007, the surface level was 6-7 cm lower than in the beginning of the growing season most likely both because of very low water table and gradual ground thaw throughout the season. Similar dynamics were observed in the following years, more or less expressed depending on the water table dynamics.

The surface level was lowering relative to the reference point over the years of study, regardless of the water table and thaw depth dynamics. The surface in the beginning of the 2010 season was $10-15 \mathrm{~cm}$ lower than in the beginning of the 2007 season. While the active layer thickness increased about $7 \mathrm{~cm}$ over the three years, the real lowering of permafrost ta- ble was about $17 \mathrm{~cm}$ (Fig. 3a, d). Ten centimeters were lost, presumably, by subsidence of the whole active layer structure upon thawing the ice contained in permafrost layers, and draining excess water.

The gradual permafrost thawing was observed during 2006-2009, but the permafrost table did not significantly change between 2009 and 2010 (Fig. 3c). An explanation may be the unusual drought in the 2010 growing season, where possibly drying of the peat reduced its thermal conductivity and thus thawing of the ground beneath.

\subsection{2 $\mathrm{CH}_{4}$ fluxes}

During the five study years, the accumulated growing season $\mathrm{CH}_{4}$ flux was highly variable in the DOY timescale (Fig. 4a) but with some striking synchronous temporal dynamics at the DASM scale (Fig. 4b). The early onset of the growing season emission was synchronized by snowmelt and soil thaw (Fig. 3). However, during the second week the rising flux rates started to differ. The main difference in the flux rates between the different seasons was observed during the first 30-40 days after snowmelt, and after this point in time the flux curves for 2006-2009 gathered towards almost identical mean values. During 2010, $\mathrm{CH}_{4}$ emission had the same pattern, but the level of emissions in the second half of the growing season was lower than in previous years. In relation to this distinct flux pattern we will in the following discuss the parameters most well known from the literature to be controlling methane emissions from wetlands.

The most recognized factors affecting $\mathrm{CH}_{4}$ efflux in wetlands are the temperature and the water table (e.g. Bubier et al., 1993; Dise et al., 1993; Christensen et al., 2003a; Pelletier et al., 2007; Elberling et al., 2008; Glaser and Chanton, 2009). In our study, the temperatures during the first part of the growing season could not explain the differences in $\mathrm{CH}_{4}$ emissions between years. The warmest first 30 days of the growing season were in 2008 (Tables 1, 2), while $\mathrm{CH}_{4}$ fluxes were the lowest within the $5 \mathrm{yr}$ (Table 2, Fig. 4). The highest $\mathrm{CH}_{4}$ emission peak was in 2007 (Fig. 4), a year with mild air temperatures during the first 30 days of the growing season. All other ways of handling air temperature (averages for June and July separately, JJA overall, etc. - see Table 1) also did not show any immediate correlation with the differences in observed methane emissions between years. Air temperature variations in the last part of the growing seasons (remembering the seasons were shifted with respect to calendar time) were also quite large between the years, while the $\mathrm{CH}_{4}$ fluxes showed very similar values, except for 2010. For this period no correlations between $\mathrm{CH}_{4}$ fluxes and air temperatures were found. Air temperature has mainly indirect effect on the processes involved in methane emission; however, it is widely used for models, flux interpolations and upscaling because air temperature data are easier to obtain than proper soil temperature data. In the case of the Zackenberg 
Table 3. Linear and exponential correlation parameters between growing season average $\mathrm{CH}_{4}$ flux $\left(\mathrm{CH}_{4}\right)$ and growing season averages for soil temperature at 5,10 and $15 \mathrm{~cm}$ depths $\left(T_{5}, T_{10}\right.$ and $\left.T_{15}\right)$ and water table level (WTL).

\begin{tabular}{|c|c|c|c|c|c|}
\hline Equation & Parameter & 2007 & 2008 & 2009 & 2010 \\
\hline $\mathrm{CH}_{4}=a\left(T_{5}\right)+b$ & $\begin{array}{lll}R^{2} & & \\
\quad a & \\
& b\end{array}$ & $\begin{array}{l}0.85 \\
\quad 0.65 \\
\quad-0.57\end{array}$ & $\begin{array}{l}0.08 \\
\quad 0.06 \\
0.43\end{array}$ & $\begin{array}{l}0.76 \\
\quad 0.20 \\
\quad 0.24\end{array}$ & $\begin{array}{l}0.91 \\
\quad 0.30 \\
\quad-0.16\end{array}$ \\
\hline $\mathrm{CH}_{4}=a\left(T_{10}\right)+b$ & $\begin{array}{l}R^{2} \\
\quad a \\
\quad b\end{array}$ & $\begin{array}{l}0.86 \\
\quad 0.74 \\
\quad-0.36\end{array}$ & $\begin{array}{l}0.22 \\
\quad 0.10 \\
\quad 0.21\end{array}$ & $\begin{array}{l}0.82 \\
\quad 0.22 \\
\quad 0.24\end{array}$ & $\begin{array}{l}0.92 \\
\quad 0.36 \\
\quad-0.16\end{array}$ \\
\hline $\mathrm{CH}_{4}=a\left(T_{15}\right)+b$ & $\begin{array}{ll}R^{2} & \\
\quad a & \\
& b\end{array}$ & $\begin{array}{l}0.73 \\
\quad \begin{array}{l}1.30 \\
\quad-0.97\end{array}\end{array}$ & $\begin{array}{l}0.60 \\
\quad 0.22 \\
\quad 0.06\end{array}$ & $\begin{array}{l}0.72 \\
\quad 0.30 \\
0.54\end{array}$ & $\begin{array}{l}0.57 \\
\quad 0.50 \\
0.12\end{array}$ \\
\hline $\mathrm{CH}_{4}=a \cdot \exp \left(b \cdot T_{5}\right)$ & $\begin{array}{l}R^{2} \\
\quad a \\
\quad b\end{array}$ & $\begin{array}{l}0.86 \\
\quad 0.23 \\
\quad 0.67\end{array}$ & $\begin{array}{l}0.19 \\
\quad 0.20 \\
\quad 0.10\end{array}$ & $\begin{array}{l}0.63 \\
0.20 \\
0.38\end{array}$ & $\begin{array}{l}0.91 \\
\quad 0.37 \\
\quad 0.17\end{array}$ \\
\hline $\mathrm{CH}_{4}=a \cdot \exp \left(b \cdot T_{10}\right)$ & $\begin{array}{ll}R^{2} & \\
\quad a & \\
& b\end{array}$ & $\begin{array}{l}0.88 \\
\quad 0.27 \\
\quad 0.71\end{array}$ & $\begin{array}{l}0.41 \\
\quad 0.32 \\
\quad 0.06\end{array}$ & $\begin{array}{l}0.71 \\
\quad 0.24 \\
\quad 0.37\end{array}$ & $\begin{array}{l}0.90 \\
\quad 0.44 \\
\quad 0.17\end{array}$ \\
\hline $\mathrm{CH}_{4}=a \cdot \exp \left(b \cdot T_{15}\right)$ & $\begin{array}{lll}R^{2} & & \\
& a \\
& b\end{array}$ & $\begin{array}{l}0.79 \\
\quad 0.48 \\
\quad 0.55\end{array}$ & $\begin{array}{l}0.77 \\
\quad 0.55 \\
0.06\end{array}$ & $\begin{array}{l}0.72 \\
0.34 \\
0.47\end{array}$ & $\begin{array}{l}0.64 \\
\quad 0.64 \\
\quad 0.23\end{array}$ \\
\hline $\mathrm{CH}_{4}=a(\mathrm{WTL})+b$ & $\begin{array}{ll}R^{2} & \\
\quad a & \\
\quad b\end{array}$ & $\begin{array}{l}0.43 \\
0.20 \\
\quad 4.19\end{array}$ & $\begin{array}{r}0.32 \\
-0.25 \\
0.80\end{array}$ & $\begin{array}{l}0.10 \\
-0.11 \\
1.02\end{array}$ & $\begin{array}{l}0.67 \\
\quad 0.06 \\
1.96\end{array}$ \\
\hline $\mathrm{CH}_{4}=a \cdot \exp (b \cdot \mathrm{WTL})$ & $\begin{array}{ll}R^{2} & \\
\quad a & \\
\quad b\end{array}$ & $\begin{array}{l}0.45 \\
\quad 0.07 \\
\quad 3.64\end{array}$ & $\begin{array}{r}0.18 \\
-0.38 \\
0.46\end{array}$ & $\begin{array}{r}0.10 \\
-0.14 \\
0.73\end{array}$ & $\begin{array}{l}0.57 \\
\quad 0.07 \\
2.02\end{array}$ \\
\hline
\end{tabular}

fen presented here such air-temperature-based models will not work.

Soil temperature data (Fig. 1, Table 2) are also not in line with interannual variability of $\mathrm{CH}_{4}$ fluxes. Soil temperatures during the first 30 days of the season were higher in 2008 than in 2009, while in terms of the methane fluxes the opposite was the case. The next 30 days' temperatures were significantly different, while the fluxes were approaching each other. During the last part of the growing season, the fluxes in 2007 and 2009 (and, probably, in 2008) were almost identical, while soil temperature at $10-15 \mathrm{~cm}$ was about twice as high in 2009 compared with 2007 and 2008.

Within individual years, correlations between soil temperatures and $\mathrm{CH}_{4}$ flux can be found (Table 3), both by linear and exponential regressions. At first view, this corresponds with similar findings at a variety of scales ranging from laboratory studies (Svensson and Roswall, 1984) to multiyear and site studies (Christensen et al., 2003a). However, this simple regression modelling does not work for more than one season in our case. For example, linear regression between soil temperature and $\mathrm{CH}_{4}$ flux has very high $R^{2}$ values of $0.86,0.82$ and 0.92 for 2007, 2009 and 2010, respectively, but the slopes of these linear regression functions are very different (Table 3). The same applies to exponential regressions. Most probably, highly pronounced seasonality both in soil temperatures and in $\mathrm{CH}_{4}$ fluxes is typical for this Arctic environment with its short summer, and this causes statistical correlation between them within each season. However, this correlation may not be applicable to other years.

Comparable multiyear studies in a temperate fen (Sallie's Fen, NH, USA, $43^{\circ} \mathrm{N}$; Treat et al., 2007) and a temperate bog (Mer Bleue Bog, ON, Canada, $45^{\circ} \mathrm{N}$; Moore et al., 2011) also report good correlation of $\mathrm{CH}_{4}$ fluxes with temperature within individual years and weak correlation for $5 \mathrm{yr}$ combined. Among many differences between the three sites, the most remarkable may be the distinction in the seasonal $\mathrm{CH}_{4}$ flux pattern. At Sallie's Fen the fluxes slowly increase throughout a season, peaking in August, which coincides 
with highest seasonal temperatures. At Mer Bleue Bog the pattern was similar, but as the measurements were continued longer into autumn (May-November) than at Sallie's Fen (May-August), the seasonal correlation of $\mathrm{CH}_{4}$ fluxes with temperature was affected by variations in autumn fluxes. In our study the peak of $\mathrm{CH}_{4}$ fluxes was usually closer to the beginning of the season, about DASM 20-30 (Fig. 4b), which may or may not coincide with the warmest part of the season (Fig. 1). Those peaks, carrying most of the seasonal emission and most of the interannual flux variation, seem to be a feature of a high-latitude wetland.

Compared with studies at a sub-Arctic mire (Stordalen, Sweden, $68^{\circ} \mathrm{N}$ - Bäckstrand et al., 2008; JackowiczKorczynski et al., 2010), our correlations between $\mathrm{CH}_{4}$ fluxes and soil temperatures within the separate growing seasons are even higher. During four seasons of an automatic chamber study (Bäckstrand et al., 2008), the coefficient of determination $\left(R^{2}\right)$ of a linear regression between total hydrocarbon (THC) fluxes and air and soil temperatures only occasionally reached 0.6 (2006, Sphagnum site, night measurements) and was usually much weaker; in our study (Table 3) correlations with $R^{2}>0.7$ are usual for individual years. Such a difference can have a number of explanations: THC fluxes, even being dominated by $\mathrm{CH}_{4}$, have more mixed sources; seasonality is stronger at higher latitudes, both for soil temperature and $\mathrm{CH}_{4}$ fluxes, which increases their apparent correlation. However, Bäckstrand et al. (2008) have also documented the difference in regression slopes between the years (interannual variability), which they could not explain. An eddy covariance $\mathrm{CH}_{4}$ study (Jackowicz-Korczynski et al., 2010) has shown better correlation between $\mathrm{CH}_{4}$ fluxes and temperature $\left(R^{2}=0.50\right.$ to 0.77$)$. During two years of measurements both temperature and $\mathrm{CH}_{4}$ fluxes had quite similar dynamics during the growing season; however, to examine interannual variability longer time series would be needed.

$\mathrm{A} \mathrm{CH}_{4}$ flux study in the Arctic tundra (Samoylov Island, northern Siberia, $72^{\circ}$ N; Wille et al., 2008) has shown a high correlation with soil temperature within two subsequent halfseasons $\left(R^{2}=0.67\right)$. Our results are in line with this correlation - the coefficients for single years usually being even higher. Wille et al. (2008) tested a more complicated model, incorporating friction velocity in addition to the soil temperature (and three parameters determined by the fit process), and achieved with this a further and even better fit with their 2003-2004 data $\left(R^{2}=0.74\right)$. However, being applied with the same fit parameters to the data from the 2006 growing season (Sachs et al., 2008), it performed much weaker $\left(R^{2}=0.40\right)$. If the same model was fit to the 2006 dataset $\left(R^{2}=0.63\right)$, the parameters were two fold different from those which fit the 2003-2004 dataset (Table 1 in Sachs et al., 2008). This fact is well in line with our finding in Zackenberg (Table 3), confirming that good correlations within individual years do not necessarily work at the multiyear scale. Again, a longer time series from Samoylov Island would be needed to further examine the interannual variability at this site.

Another study in the Arctic (Chokurdakh, NE Siberia, $70^{\circ} \mathrm{N}$ - Parmentier et al., 2011b) showed correlations between $\mathrm{CH}_{4}$ flux (EC measurements) and soil temperature with $R^{2}$ from 0.33 to 0.5 for two consecutive growing seasons together.

Methanogenesis (as well as methanotrophic oxidation) is a temperature-dependent metabolic process, and there is no way how the methane production can be detached from being affected by a soil temperature. However, the interannual variability of the fluxes found in this study cannot be explained by temperature, which should mean that it is not the production itself, but some other processes that play an overriding role in controlling the net emission.

Another widely used predictor for $\mathrm{CH}_{4}$ emission is the water table position (e.g. Dise et al., 1993; Daulat and Clymo, 1998; Hargreaves and Fowler, 1998; Friborg et al., 2000; Elberling et al., 2008). In our study water table dynamics were also very different from the methane flux dynamics, and we failed to find any reasonable correlation between them, except for the year 2010 (Table 3). For the first 30 days of the growing season (Fig. 2, Table 2), water table was highest in 2006 (second large $\mathrm{CH}_{4}$ emission) and lowest in 2010 (third large $\mathrm{CH}_{4}$ emission). Comparing the two-year intervals 2006-2007 (high water table, high $\mathrm{CH}_{4}$ emission) and 20082009 (lower water table, lower emission) may look promising. However, within the two-year intervals this logic does not work. The flux in 2007 was higher than in 2006 at DASM 20-40, when the water table was much lower. The flux in 2009 was about twice as high as in 2008 , while water table was almost the same. At DASM 30-60 water table was above the surface in 2006, slightly below the surface in 2008, and far below the surface in 2007 and 2009. This distribution was not reflected in $\mathrm{CH}_{4}$ fluxes (although slightly higher fluxes in 2006 could be explained by possible suppressed methanotrophic activity). Fluxes at DASM 30-60, 2008 were virtually the same as in 2007 and 2009, while water table level differed dramatically. The same situation continued for the remainder of the growing season.

We tried to find a best parameter, correlating with $\mathrm{CH}_{4}$ flux, upon different spatial soil zones created by water table, thaw depth and surface level. These are saturated zone thickness (from the frost table to the water table), aerobic zone thickness (from the water table to the surface), aero$\mathrm{bic} /$ anaerobic ratio (quotient of the two above), etc. None of these parameters are good enough to explain $\mathrm{CH}_{4}$ flux dynamics in our study.

The lack of water table effect on $\mathrm{CH}_{4}$ fluxes during the beginning of the growing season may be explained by the fact that despite the difference in water table it was in all years above or at the surface, providing similar conditions for methanogenic versus methanotrophic activity distribution. Thus, the variability of $\mathrm{CH}_{4}$ fluxes during the first part of the season neither correlates to water table position nor 
contradicts it. More surprising is the lack of any significant correlation between water table position and fluxes in the second half of the season. Years with lower water table have higher $\mathrm{CH}_{4}$ fluxes, and vice versa. Within each year $\mathrm{CH}_{4}$ fluxes seem to stay on their pattern regardless of even dramatic changes in the water table. A possible explanation could be that the open water table measurements in a hole are not the same as the level of $100 \%$ water saturation in the peat matrix. Due to the capillary effect, water can stay higher than we measured. However, during dry parts of the growing seasons in 2007 and 2009, the mosses and the surface peat were visually clearly dry, so there was certainly an increased aerobic horizon that by conventional knowledge should stimulate methanotrophic activity. In short, it appears as if the net emissions are largely independent of the water table, and this may be explained by the water table fluctuations being all (or most of them) above a certain threshold beyond which the water table no longer is a major controlling factor. It has been shown before that the water table acts in a nonlinear way and rather as an on/off switch in relation to the net $\mathrm{CH}_{4}$ fluxes (Christensen et al., 2003a). It seems that at this site the $\mathrm{CH}_{4}$ emissions are turned on and therefore acting most years independent of the water table fluctuations.

However, in 2010 the water table dynamics were exceptional. Started from the surface at snowmelt, it started to decrease already at DASM 18 and was going down consistently for more than 60 days (Fig. 2b). This unusual drought was the most probable reason for the unusual $\mathrm{CH}_{4}$ flux dynamics (Fig. 4b): net emission started to decrease after DASM 20 (earlier than in 2006-2009) and came to much lower values at DASM 60-90 than in previous years. We may hypothesize that water table level is not a limiting factor for $\mathrm{CH}_{4}$ emission at our site while it is above $20 \mathrm{~cm}$ depth, as in 2006-2009, but become such if it falls deeper, as it did in 2010.

Strong interannual variations in water table level were also reported for Sallie's Fen (Treat et al., 2007), where the usual trend was decreasing of water table level throughout a measurement season (May-August), while the $\mathrm{CH}_{4}$ fluxes were increasing. This gave rise to a negative correlation within individual seasons, and no significant correlation interannually (Treat et al., 2007). In our study the seasonal trend in water table was similar, but the seasonal pattern in $\mathrm{CH}_{4}$ fluxes was quite different, as discussed above. This led to a positive correlation between water table and $\mathrm{CH}_{4}$ emission within individual seasons. Most likely, in both studies these correlations were coincidental, and water table was not the main factor affecting $\mathrm{CH}_{4}$ fluxes.

At Mer Bleue Bog (Moore et al., 2011) seasonality was slightly different, with relatively high water table during the spring, falling during the summer and rising again during the autumn. At this site variations of water table had a higher amplitude and were positively correlated with $\mathrm{CH}_{4}$ fluxes at the seasonal scale.

At Stordalen a weak correlation between $\mathrm{CH}_{4}$ fluxes and water table level was found at some sites (Bäckstrand et al., 2008), while no significant correlation found in others (Bäckstrand et al., 2008; Jackowicz-Korczynski et al., 2010).

The Samoylov Island study (Wille et al., 2008) reported no correlation between methane flux and water table position.

In Chokurdakh (Parmentier et al., 2011b) the correlation between $\mathrm{CH}_{4}$ flux and water table was reported $\left(R^{2}\right.$ from 0.27 to 0.58 ) for 1.5 growing seasons (second half of 2008 and whole 2009 season). However this correlation is mainly based on interannual variability: during 2008 the water table and the $\mathrm{CH}_{4}$ fluxes were generally higher than during 2009. A similar pair can be found within our data, e.g. 2009 and 2010, if the peak in the beginning of the growing season is not accounted (this peak was not present in the Chokurdakh study). The main difference with our site is that at Chokurdakh the water table was staying above the surface all the time.

We suggest that methanotrophic activity (here we mean oxidation in the methanotrophic layer, unlike rhizospheric oxidation) during the normal 2006-2009 years, was not a key factor controlling $\mathrm{CH}_{4}$ flux in our study either. According to a common scheme (e.g. Joabsson et al., 1999; Whalen, 2005; Glaser and Chanton, 2009; Lai, 2009) methane is produced in the anaerobic soil layer, to some extent stored in the soil (mainly as entrapped bubbles), transported to the surface, partly passed through the methanotrophic filter, and the remaining is emitted to the atmosphere. There are three main mechanisms of methane transport through the soil (e.g. Cicerone and Shetter, 1981; Conrad, 1996; Whalen, 2005; Glaser and Chanton, 2009; Lai, 2009): molecular diffusion, plant-mediated transport and ebullition. The surficial methanotrophic oxidation can intercept a large fraction of diffusively transported $\mathrm{CH}_{4}$ (Whalen and Reeburgh, 1990; Whalen, 2005). In some cases mossassociated methane oxidation can be substantial even below the water table (Parmentier et al., 2011a; Liebner et al., 2011). Root-associated methanotrophy (rhizospheric oxidation, King, 1994; Calhoun and King, 1998) reduces the amount of $\mathrm{CH}_{4}$ emitted by the vascular transport mechanism. In our study the ebullition was estimated to have a negligible share, and due to physical limitations the molecular diffusion cannot provide any high rates of emission either (Christensen et al., 2003b). This means plant-mediated transport remains the main mechanism at work. By definition, this should be controlled by the quantity, quality and activity of vascular plants: the same plants affect methanogenic activity (by providing substrates) and root-associated methanotrophic activity (by providing oxygen). Unfortunately, any detailed analysis of the vegetative cover is not yet available from the automatic chambers (which are part of a long-term monitoring program and therefore should stay untouched from destructive harvests etc). However, the measured $\mathrm{CO}_{2}$ exchange can be used as an indirect proxy of the activity of the plants. 


\subsection{3 $\mathrm{CO}_{2}$ fluxes}

In this study $\mathrm{CH}_{4}$ fluxes were the main focus, and the measurements of $\mathrm{CO}_{2}$ were complimentary. For this reason the chambers were not designed to provide both light (various levels of it) and dark measurements, as is the usual praxis for $\mathrm{CO}_{2}$ studies using the same technique (e.g. Joabsson and Christensen, 2001). The chambers were made of transparent Plexiglas, connected by aluminum 3-5 cm-wide verges. So the $\mathrm{CO}_{2}$ measurements may be defined as light measurements although the PAR level inside the chambers was about $20 \%$ lower than ambient. This is a known artifact of the chamber method, and in this study we did not attempt to correct it. Because of the high latitude, the real darkness did not occur until the end of July, so no dark respiration measurements were taken during the central part of the growing season. For this reason we did not try to estimate respiration and GPP (Gross Primary Productivity) separately. However, our net $\mathrm{CO}_{2}$ fluxes throughout the season happened to be very close to the fluxes reported earlier using combined data from eddy covariance and manual chamber methods (Nordstrøm et al., 2001), and we assume the estimations of GPP and respiration shown in the latter publication can be valid also for our study (see Supplement).

NEE dynamics during the start of the season were found to be affected by date of snowmelt (Fig. 5), while the drivers controlling the decrease of the GPP towards the end of the growing season probably have a more mixed nature. The PAR level, important for plants' productivity, decreases with sunlight angle (DOY timeline). The temperature is another important factor both for the respiration and $\mathrm{CO}_{2}$ fixation; the decrease in temperature at the end of the season correlates roughly with the calendar date (DOY), but progresses differently in different years - for example, in 2008 and 2010 positive temperatures kept three weeks longer than in 2007 and 2009. In our dataset (Fig. 5) two out of five years had no NEE data for the end of growing season, and the data from 2007 do not show any clear pattern during this period because of weather (unstable PAR). The NEE $\mathrm{CO}_{2}$ fluxes from 2008 and 2010 are very different between DASM 30 and 60 , but both reach the NEE compensation point by about DASM 60. However, 2008 and 2010 datasets cannot be directly compared in terms of $\mathrm{CO}_{2}$ exchange because of an extreme drought in 2010, so the question of whether we should look for synchronism of $\mathrm{CO}_{2}$ fluxes in the end of growing season in DOY or DASM timescales is open.

The most complete NEE dataset was obtained for the first 30-40 DASM. The initial period of positive net flux was significantly shorter and had lower magnitude than was reported in the earlier study (Nordstrøm et al., 2001). Then efflux turned to negative (net $\mathrm{CO}_{2}$ uptake), with the highest rate in 2008 and lowest in 2009 (Table 2). Surprisingly, this did not correspond with the rates of $\mathrm{CH}_{4}$ flux development (Fig. 4). The peaks in NEE (uptake) tend to be synchronous with the peaks in $\mathrm{CH}_{4}$ emissions, but their magnitude did not correspond: the biggest NEE peak in 2008 coincided with the smallest $\mathrm{CH}_{4}$ peak, while the second productive 2007 had the highest $\mathrm{CH}_{4}$ peak. The ranks of average $\mathrm{CH}_{4}$ and $\mathrm{CO}_{2}$ fluxes per growing season (Table 1) also do not match.

\subsubsection{Multivariate approach}

As an attempt to find a multivariate explanation for the interannual variability of $\mathrm{CH}_{4}$ fluxes, we have applied stepwise multilinear regression and a regression tree analysis, both for individual years and for the whole dataset. The applicability of such tests (as well as linear regression) may obviously be questioned due to the strong autocorrelation in data caused by seasonality; however they could be useful as descriptive measures. The predictor variables used (daily resolution) were time (DASM), NEE, soil thaw depth, soil temperature and water table level.

The stepwise regressions generally explain the $\mathrm{CH}_{4}$ flux dynamics for individual years well; $R^{2}$ values range from 0.88 to 0.96 . However, significant coefficients selected in the test varied from year to year and there was a large variation in the coefficient values; thus the results are similar to those presented in Table 3 for univariate regressions. When the stepwise regression was applied to the full dataset, the $R^{2}$ value was much lower (0.42) compared with those from individual years. The modeled $\mathrm{CH}_{4}$ flux failed to capture high fluxes in 2007 and overestimated fluxes in 2008 and 2009.

The regression tree analysis showed a similar picture, in the sense that the regression trees differed from year to year. A regression tree based on the whole dataset underestimated fluxes during 2007 and overestimated those during 2008 and 2009. When a year variable was added to the analysis, the first split divided the dataset into 2007 and 2008-2010, respectively.

Thus, both the multilinear regression and the regression tree analysis show a pattern similar to the simple regression analysis (Table 3): the seasonal dynamics of $\mathrm{CH}_{4}$ fluxes can be quite well explained by common environmental factors, but the interannual variability can not. This should indicate that one (or more) vital predictor is missing, and if we failed to find it within a growing season, we should look for something happening during autumn, winter or spring.

\subsection{Zero curtain period and freezing season}

\subsubsection{Environmental conditions}

During the zero curtain period the soil temperature stays almost constant at $0{ }^{\circ} \mathrm{C}$ and the main proportion of water in the soil turns to ice. Depending on the weather the freezing may take a shorter or longer amount of time. In our study (Table 1) it took 15 days in 2010, 16 days in 2008, 17 days in 2006 and 2007, and 27 days in 2009, where in the latter case unusually high snow precipitation caused high and early snow cover, insulating the soil. The following freeze-in 


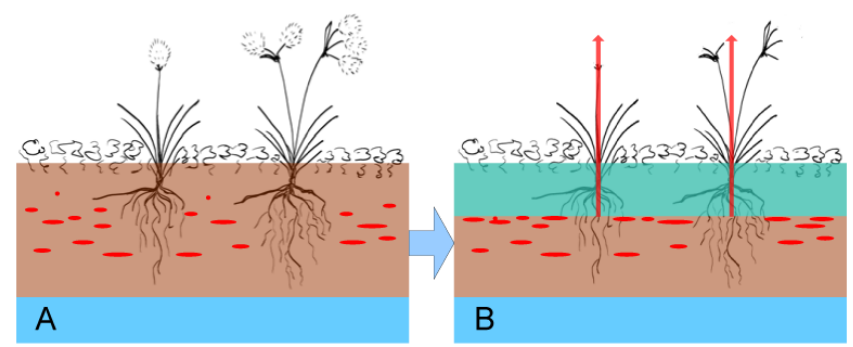

Fig. 6. Hyphotetical scheme of mechanism for late-season $\mathrm{CH}_{4}$ and $\mathrm{CO}_{2}$ emissions. A summer; $\mathbf{B}$ autumn. See the description in the text.

rates were different between years: freezing of $5-15 \mathrm{~cm}$ took only 9 days in 2008, 13-14 days in 2007 and 2010, and 20 days in 2009. We assume that the snow cover was the main factor slowing down the heat exchange in 2009. Conversely, in 2008, high amounts of rain occurred just before the freezein, and subsequently the water-saturated soil was acting as a good conductor for heat flux. The high water level in the end of the 2008 season turned to become an ice layer on the soil, which probably lowered $\mathrm{CH}_{4}$ and $\mathrm{CO}_{2}$ emissions.

\subsubsection{Post-growing season $\mathrm{CH}_{4}$ fluxes}

High $\mathrm{CH}_{4}$ fluxes in October 2007 (Fig. 4a) were coinciding with soil freezing (Fig. 1), which made us hypothesize that frost action is the main driving force for this effect (Mastepanov et al., 2008). During the growing season a significant amount of $\mathrm{CH}_{4}$ remains in the soil profile in the form of entrapped gas bubbles (e.g. Tokida et al., 2005; Mastepanov and Christensen, 2009; Glaser and Chanton, 2009). In continuous permafrost areas, freezing of the active layer both from the top (surface) and bottom (permafrost table) creates high pressure between the two freezing fronts. If the active layer is not too deep (in our case $50-60 \mathrm{~cm}$ ), this high pressure can cause gas bubbles to be squeezed out through microcracks or remaining vascular plant tissues (Fig. 6). As the pressure grows, the gas seepage follows, but when the upper frozen layer reaches some thickness the number of possible channels for emission decreases. Most likely some amount of bubbles remain trapped in the frozen soil.

At this point in time we cannot clearly determine if the autumn burst is a usual, regular or rare event. We have definitely observed it in 2007 and 2010, and in both cases the emission started to increase with freezing of upper soil horizons, came to its maximum values around the time when the frozen front was down at $15 \mathrm{~cm}$, and then decayed (Figs. 1 and 4). We probably saw the start of this burst in 2009 (we assume that slower soil freezing delayed the $\mathrm{CH}_{4}$ burst and smoothened the flux dynamics) before the station was closed for the season. We have no data for the freezing period of 2006. In 2008 the burst was not registered when it was expected to happen; perhaps we missed it because of large gaps in the data, but
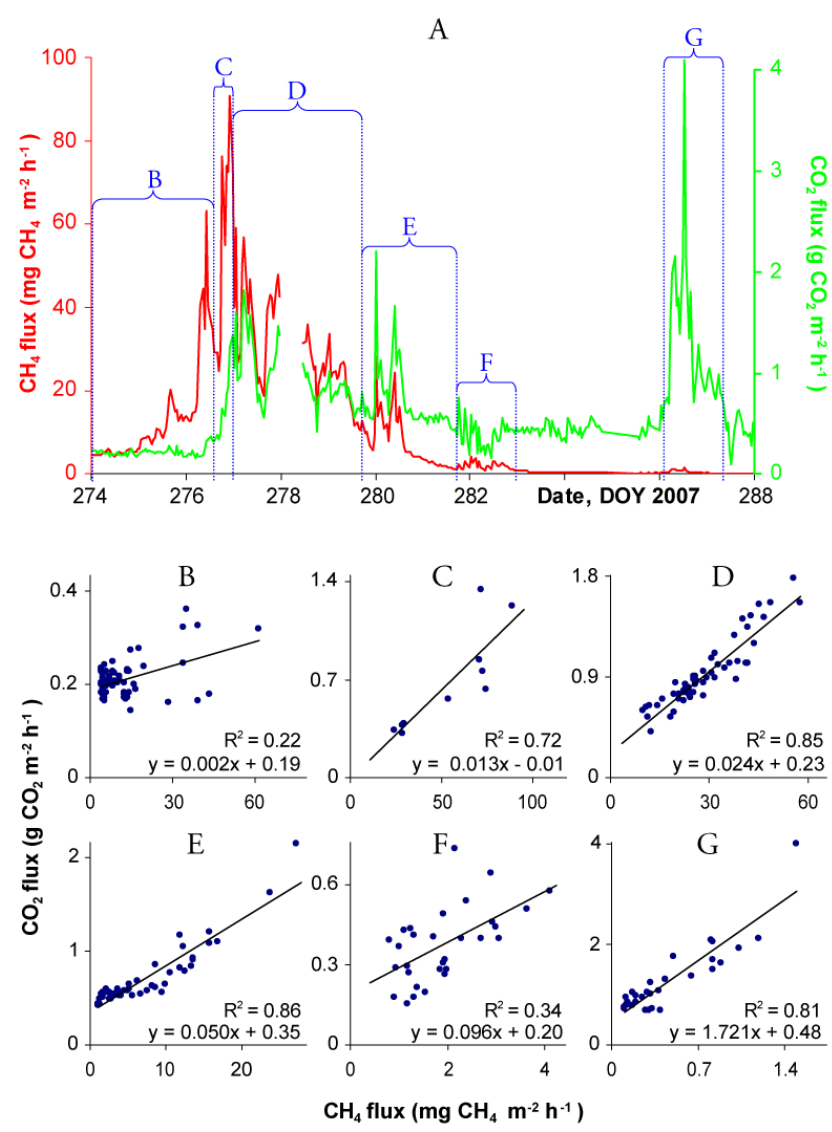

Fig. 7. Examples of freeze-in season dynamics of $\mathrm{CH}_{4}$ and $\mathrm{CO}_{2}$ fluxes in one of the chambers. $\mathbf{A} \mathrm{CH}_{4}$ (red, left axis) and $\mathrm{CO}_{2}$ (green, right axis) fluxes. $\mathbf{B}-\mathbf{G} \mathrm{CO}_{2} / \mathrm{CH}_{4}$ ratio for individual time intervals.

most probably the ice shield on the surface and fast freeze-in prevented the emission. Regardless, it seems likely that the high autumn burst does not happen every year but has some natural regularity.

During the Samoylov Island study (Wille et al., 2008), $\mathrm{CH}_{4}$ fluxes were measured into post-growing season (until 22 October 2003). The authors do not emphasize an autumn burst of $\mathrm{CH}_{4}$; however, in the data (Figs. 4, 7 and 10 in Wille et al., 2008) the first signs of this burst can be assumed during the last weeks of measurement. Soil temperature at $20 \mathrm{~cm}$ depth stayed at $0^{\circ} \mathrm{C}$ until the end of the measurement campaign, which leaves the possibility that the following peak of fluxes was missed.

Autumn 2009 methane measurements in Barrow (Sturtevant et al., 2012) found no evidence for a $\mathrm{CH}_{4}$ pulse during soil freezing. According to the authors, there is probability that it could also occur after the measurements were ended, since the soil profile was not completely frozen. The other possibility is that some high fluxes could be missed due to gaps in the data during October. Most probably, there was no huge burst like we had in 2007 in 


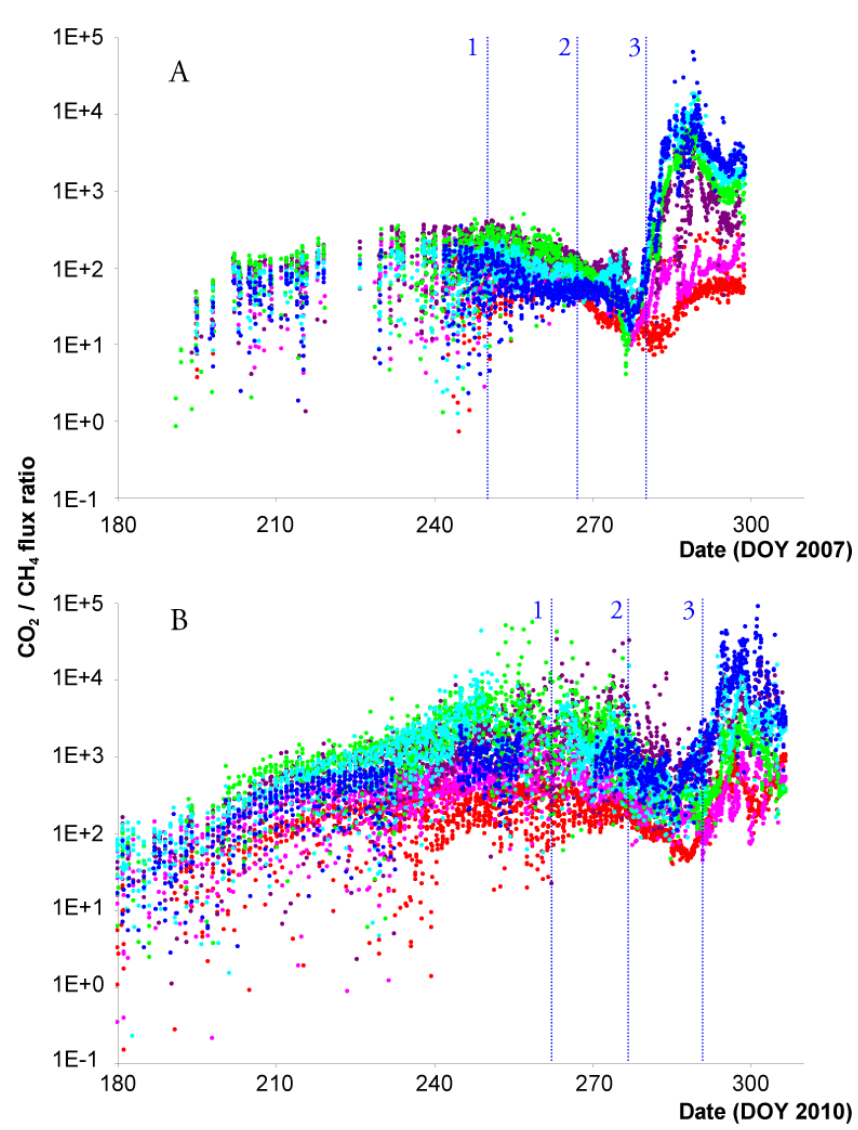

Fig. 8. Example of late-season correspondence between $\mathrm{CH}_{4}$ and $\mathrm{CO}_{2}$ fluxes. Six colors correspond to six individual chambers, each dot is $\mathrm{CO}_{2} / \mathrm{CH}_{4}$ ratio for one individual measurement. A 2007 data; $\mathbf{B} 2010$ data. 1, 2, 3: time marks (see Table 1); 1: soil temperature at $0^{\circ} \mathrm{C}$, bound between the growing season and the freezing season; 2: soil is frozen to $5 \mathrm{~cm}$ depth; 3 : soil is frozen to $15 \mathrm{~cm}$ depth.

Zackenberg; however, the study does not deny a possibility of smaller emission peaks.

Year-round $\mathrm{CH}_{4}$ flux studies at Stordalen (JackowiczKorczynski et al., 2010) did not show any signs of autumn burst. This fact may be explained by the mosaic structure of the mire: being situated in the sporadic permafrost zone, it is productive for $\mathrm{CH}_{4}$ only at wet locations that have no underlying permafrost. The dry palsa locations have permafrost, but do not provide methane production and storage.

\subsubsection{Post-growing season $\mathrm{CO}_{2}$ fluxes}

In all three years, 2007, 2009 and 2010, the autumn $\mathrm{CH}_{4}$ peak was accompanied by a corresponding $\mathrm{CO}_{2}$ peak (Fig. 5a) caused by the same physical mechanism (Fig. 6). As the entrapped gas bubbles contain a high amount of $\mathrm{CO}_{2}$ as well as $\mathrm{CH}_{4}$, according to the physical hypothesis they should be emitted together. Indeed, close-up flux dynamics at freezing time show that every single peak of $\mathrm{CH}_{4}$ is accompanied by

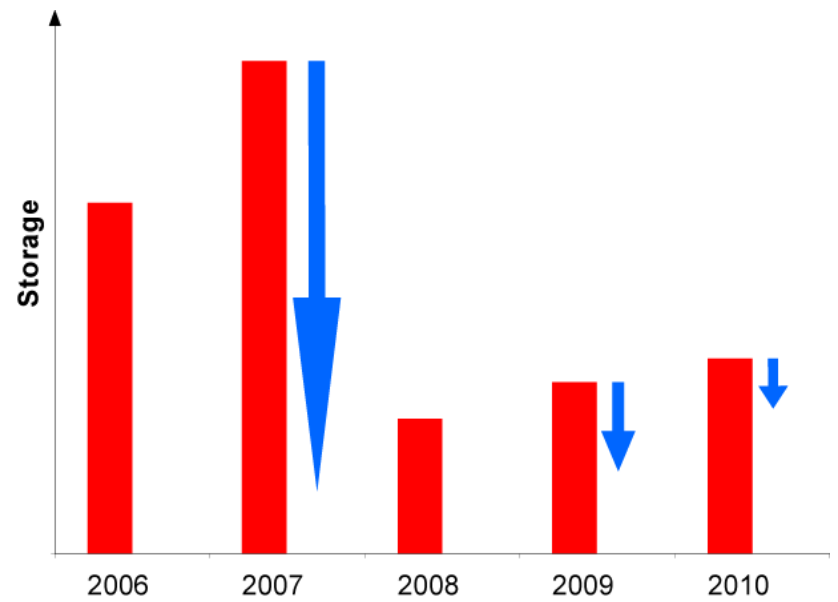

Fig. 9. Hypothetical scheme of subsurface $\mathrm{CH}_{4}$ storage changes over 5 yr. Red rectangles: estimation of storage pool during growing season; their heights on the scheme are proportional to peak emissions in Table 1. Blue arrows: estimation of discharge during autumn burst; arrow sizes correspond to cumulative $\mathrm{CH}_{4}$ emission documented during post-growing season (Table 1).

a simultaneous peak of $\mathrm{CO}_{2}$ (Fig. 7 - 2007; dynamics for 2009 and 2010 look similar, not shown). The $\mathrm{CH}_{4} / \mathrm{CO}_{2}$ ratio is almost constant for each peak, confirming that the gas has a single origin (one entrapped bubble). Such a bubble does not exhaust instantly, like it happens at ebullition, but the exhaust of one bubble takes a few hours. This confirms the idea that the gas is squeezed through very thin channels, probably the remnants of vascular plant tissues. However, the $\mathrm{CH}_{4} / \mathrm{CO}_{2}$ ratio is changing between different peaks (bubbles), starting from relatively $\mathrm{CH}_{4}$-rich in the beginning of the autumn burst to being more $\mathrm{CO}_{2}$-rich in the end. This pattern can also be explained by a physical mechanism. In the beginning of freezing the layer between permafrost and frozen soil surface contain a large amount of water. At high pressure, $\mathrm{CO}_{2}$ solubility dramatically increases, and most of the pressurized $\mathrm{CO}_{2}$ goes to solution in unfrozen water. The solubility of $\mathrm{CH}_{4}$ is much lower even at high pressures, and its fraction in the bubbles remains high. Forced by high pressure, these bubbles leave the soil and the overall amount of $\mathrm{CH}_{4}$ in the system declines. When the frost propagates, liquid water becomes ice, but the dissolved gases, now with a larger fraction of $\mathrm{CO}_{2}$, remain in the solution. The $\mathrm{CO}_{2}$ concentration in the solution rises and so does its fraction in the remaining (or new) bubbles. $\mathrm{CH}_{4}$ also migrates from the solution to the bubbles, but as its concentration in the solution was much smaller, the bubbles turn from $\mathrm{CH}_{4}$-dominated to $\mathrm{CO}_{2}$-dominated with time. The plot of the $\mathrm{CO}_{2}$ versus $\mathrm{CH}_{4}$ ratio (Fig. 8) shows alternation of those processes for the 2007 and 2010 fluxes; the similar plot for the 2009 fluxes (not shown) is not so clear due to the lower fluxes. 


\subsection{Freezing season affecting the next growing season}

If the subsurface methane pool can be significantly depleted after a growing season, it may be suggested that in the beginning of the next growing season a significant part of methane production will go to refill the subsurface pool instead of becoming emission to the atmosphere. Therefore, after a high autumn burst low $\mathrm{CH}_{4}$ fluxes can be expected in the first part of the following season. We have not enough data to confirm or disprove this hypothesis, but with some stretch it can explain the interchange of seasons with higher and lower $\mathrm{CH}_{4}$ fluxes during our study. The actual $\mathrm{CH}_{4}$ fluxes are shown in Fig. 4 and summarized in Table 1; the hypothetical dynamics of subsurface storage pools are schematized in Fig. 9.

If we assume that there were no strong $\mathrm{CH}_{4}$ burst in the end of 2006 and 2008, and at the start of 2006 the subsurface $\mathrm{CH}_{4}$ pool was partly charged, then a large fraction of the $\mathrm{CH}_{4}$, produced during the growing season 2006 was emitted instantly, leading to high fluxes. Another part stayed in the soil, charging the storage pool even more, and this pool was sustained over winter. In 2007, when it was charged even more, a higher emission was detected. In the autumn of 2007 the strong burst occurred, and the subsurface $\mathrm{CH}_{4}$ pool discharged. Then, in the beginning of the growing season 2008, the emission was very low - almost all the production went to recharge the subsurface pool. In the beginning of the growing season 2009, the pool was more charged, and a higher amount of $\mathrm{CH}_{4}$ went to emission - as evident from the first part of 2009 showing higher emission rates than in 2008. The autumn discharge in 2009 was relatively small and did not overcome the recharge during the growing season, so the pool increased between 2009 and 2010, and peak emission 2010 was higher than 2009.

Unfortunately we have no direct measurements of subsurface $\mathrm{CH}_{4}$ pool transformations during our study. The best possible approximation for the discharge of the storage pool due to freezing time burst (blue arrows in Fig. 9) is the cumulative post-growing season $\mathrm{CH}_{4}$ emission, documented in our measurements (Table 1). This measure is not entirely correct because it includes the declining background emission during zero curtain period and freezing season, and it does not include the missed late part of freezing season emission. The approximation of the total amount of $\mathrm{CH}_{4}$ in the subsurface storage pool during each growing season (red bars in Fig. 9) was based on the idea that the peak season emission reflects this storage replenishment; thus the red bars in Fig. 9 are proportional to peak $\mathrm{CH}_{4}$ emissions in Table 1, and sized arbitrarily to match blue arrows (discharge).

Being evidently speculative, this figure, however, is not unrealistic. Very roughly, the longest blue arrow should be about $4-5 \mathrm{~g} \mathrm{C} \mathrm{m}^{-2}$ (the measured cumulative emission during post-growing season 2007 was $3.76 \mathrm{~g} \mathrm{C} \mathrm{m}^{-2}$ ), so the highest red bar about $5-6 \mathrm{~g} \mathrm{C} \mathrm{m}^{-2}$ and the lowest about $1-2 \mathrm{~g}$ $\mathrm{C} \mathrm{m}^{-2}$. This magnitude seems realistic; for example, Strack and Waddington (2008) reported the total peat profile bub-

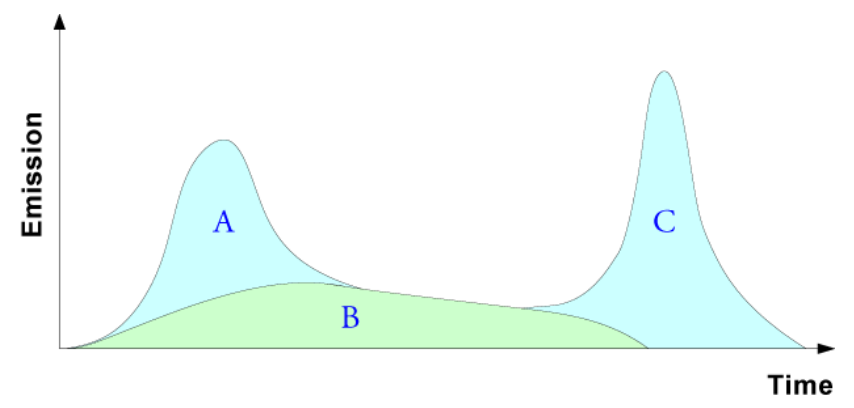

Fig. 10. Hypothetical scheme of bicomponent $\mathrm{CH}_{4}$ emission. A $\mathrm{CH}_{4}$ based on slow-turnover carbon from freeze/thaw-degraded matter; $\mathbf{B ~} \mathrm{CH}_{4}$ based on fast-turnover carbon from root exudation; $\mathrm{C} \mathrm{CH}_{4}$ stored in soil, mainly A-originated.

ble $\mathrm{CH}_{4}$ stock of $0.3-1.0 \mathrm{~mol} \mathrm{~m}^{-2}\left(3.6-12 \mathrm{~g} \mathrm{C} \mathrm{m}^{-2}\right)$ in $1.5 \mathrm{~m}$ peat profile, or $0.3-0.8 \mathrm{~mol} \mathrm{~m}^{-2}\left(3.6-9.6 \mathrm{~g} \mathrm{C} \mathrm{m}^{-2}\right)$ in its upper $60 \mathrm{~cm}$, for a boreal Canadian fen.

If we assume, that the estimated maximum 2007 storage $\left(5-6 \mathrm{~g} \mathrm{C} \mathrm{m}^{-2}\right)$ was distributed within $20 \mathrm{~cm}$ anaerobic layer $\left(200 \mathrm{~L}\right.$ of waterlogged soil), then it fits with $\mathrm{CH}_{4}$ solubility in water at $0^{\circ} \mathrm{C}$ (Wilhelm et al., 1977) which is $4.6 \times 10^{-5} \mathrm{~mol} \mathrm{~mol}^{-1}$, or $6.13 \mathrm{~g}$ per $200 \mathrm{~L}$.

Analyzing the relatively slow increase of subsurface storage pool during 2006-2007 and 2008-2010 (Fig. 9), we can assume that the accumulation of the 2007 amount would need at least 2-3 yr without a significant discharge. In light of this, the Barrow study (Sturtevant et al., 2012) was not ideal for catching an autumn discharge: two out of three sites were experimentally manipulated during the early growing season of the same year (2009) when the autumn measurements were carried out. During this manipulation (pumping large amounts of water from the drained section to the flooded section), the subsurface $\mathrm{CH}_{4}$ pool could be altered in both due to degassing. The $\mathrm{CH}_{4}$ flux dataset form the third, unmanipulated, site unfortunately ended around 1 September, i.e. too early for a potential burst to be discovered.

Our hypothesis that a single strong autumn burst can affect growing season $\mathrm{CH}_{4}$ fluxes for a few following years is directly supported by our data. However, the question remains of why during the second halves of the growing seasons (DASM 45-90) the fluxes were so similar between the years 2006-2009, when the first half of the next season remembered the state at the first half of the previous one. This question lead us to propose another hypothesis: $\mathrm{CH}_{4}$ emission during the growing season has two different components with different sources and mechanisms (Fig. 10).

The idea of fast and slow carbon turnover is not new (Chanton et al. 1995; Ström et al., 2005), so it may be assumed that the $\mathrm{CH}_{4}$ peak in the first half of the growing season (Fig. 10a) has mainly slow-turnover carbon origin - say, from fine roots or soil microorganisms' cells damaged during previous freezing season (e.g. Soulides and Allison, 1961; Skogland et al., 1988). When the soil thaws, these organic 
compounds are involved in the microbial turnover and part of them become $\mathrm{CH}_{4}$. Such $\mathrm{CH}_{4}$ production goes on in the whole anaerobic horizon, including the locations relatively far from the vascular plant roots, where the generated $\mathrm{CH}_{4}$ becomes entrapped and forms bubbles. Such locations have limited capacities for gas storage, and the more they fill, the more gas is migrating out towards the surface or plant roots and escaping to the atmosphere (Fig. 10a). After a few weeks this source of organic substrate depletes, and this type of methanogenic activity suspends until the next season. At the same time, another type of methanogenesis is progressing - feeding on fast-turnover carbon, namely root exudates (Fig. 10b). This process is taking place in the rhizosphere, and only gathers its full rate when the vascular plants come to their maturity in the middle of the season. This $\mathrm{CH}_{4}$ is generated close to the roots, and finds its way through the plant tissues quite fast (background emission; Christensen, 1993). To a large extent it escapes methanotrophic oxidation, so for this part of $\mathrm{CH}_{4}$ the emission is directly controlled by production based on substrate availability and the latter, in turn, determined by root exudation of certain vascular plants (Ström et al, 2012). This fast-turnover-carbonoriginated $\mathrm{CH}_{4}$ does not interfere much with the subsurface storage pool formed by early-season $\mathrm{CH}_{4}$ production from slow-turnover carbon. As root exudation decreases with plants senescence, methanogenesis also decreases and so the emission (Fig. 10b). Then the soil starts to freeze, and under certain conditions the slow-turnover-carbon-originated $\mathrm{CH}_{4}$ can burst out (Fig. 10c). Thus the peak of a growing season $\mathrm{CH}_{4}$ emission (around DASM 30) and the freezing season burst are linked by the same source and storage pool, while the background $\mathrm{CH}_{4}$ emission during the second half of a growing season is independent and related to plants.

The hypothesis of bicomponent $\mathrm{CH}_{4}$ emission at our site does fit our data very well. During the first half of a growing season the emissions (originated by slow-turnover carbon; Fig 10a) vary interannually and are affected by previous autumn discharge (Fig. 9); during the second half of a growing season the emissions (originated by fast-turnover carbon; Fig. 10b) are less variable, with the exception of 2010, when unusual draught affected the vegetation.

This hypothesis can also explain different diurnal patterns of $\mathrm{CH}_{4}$ emission at our site throughout the season (see Supplement).

The possible carry-over effects from one year to the next emphasize the importance of multiyear studies, and the spatial heterogeneity of responses to the same drivers shows the need for integrated measurement approaches across space and time. Continued monitoring of $\mathrm{CH}_{4}$ emissions as presented in this paper is needed at multiple sites with multiple methods to improve our understanding of the controls on high-Arctic emissions. One of the questions would be how usual, or how frequent, the autumn burst is for different sites where it can be expected according to the suggested mechanism; i.e. where the $\mathrm{CH}_{4}$ production during a grow- ing season is substantial, the active layer thickness is reasonable (e.g. 50-60 cm) and the anaerobic horizon is capable of holding entrapped $\mathrm{CH}_{4}$ until the freezing season. This question can be resolved by multiyear flux monitoring at a number of Arctic sites. A more general study could be one addressing the quantitative inventory of subsurface $\mathrm{CH}_{4}$ pools and their dynamics within and between seasons. If a certain amount of $\mathrm{CH}_{4}$ is stored during the growing season, where does it go? Is it all emitted before the end of the season? Is it oxidized? If some fraction of this pool sustains until freezing time, what happens with it? If some fraction sustains even through the freezing period, does it stay intact over winter? What happens during soil thaw next spring? Is it feasible to close the annual budget of $\mathrm{CH}_{4}$ storage? To answer these and similar questions, intensive studies of dissolved and entrapped $\mathrm{CH}_{4}$ concentrations (e.g. by bimembrane diffusion probes; Mastepanov and Christensen, 2008), together with high-resolution monitoring of entrapped bubble volumes (e.g. by dielectric permittivity measurements; Comas and Slater, 2007), can be used. The hypothesis of bicomponent $\mathrm{CH}_{4}$ emission could be examined by a study of natural $\mathrm{CH}_{4}$ stable isotope composition $\left({ }^{13} \mathrm{C}\right.$ and $\left.\mathrm{D}\right)$ throughout the growing season and freezing period, or by labeling experiments in situ.

The first $5 \mathrm{yr}$ of methane monitoring at Zackenberg have provided a unique dataset of multiyear high time resolution $\mathrm{CH}_{4}$ flux measurements at an Arctic site. It shows the great importance of interannual variability and also a lack in our current capability of explaining this variability using commonly known factors controlling methane emission at the seasonal timescale, i.e. temperature and water table position. We need more multiple year studies from different places in the Arctic to help improve our understanding in this context. The dataset presented has expanded our knowledge about fluxes and processes occurring after the end of the growing season and shown a potential importance of these shoulder season processes for multiyear dynamics in storage and emissions of $\mathrm{CH}_{4}$ in the Arctic.

\section{Supplementary material related to this article is available online at: http://www.biogeosciences.net/10/ 5139/2013/bg-10-5139-2013-supplement.pdf.}

Acknowledgements. The presented work has been carried out under the auspices of the GeoBasis part of the Greenland Ecosystem Monitoring program. The authors have seen support also from the Swedish Research Councils VR and FORMAS as well as the Linné Center LUCCI, the Nordic Center of Excellence DEFROST and recently the EU PAGE21 project.

Edited by: M. Bahn 


\section{References}

Bäckstrand, K., Crill, P. M., Mastepanov, M., Christensen, T. R., and Bastviken, D.: Total hydrocarbon flux dynamics at a subarctic mire in northern Sweden, J. Geophys. Res., 113, G03026, doi:10.1029/2008JG000703, 2008.

Bubier, J., Costello, A., Moore, T. R., Roulet, N. T., and Savage, K.: Microtopography and methane flux in boreal peatlands, northern Ontario, Canada, Can. J. Botany, 71, 1056-1063, 1993.

Calhoun, A. and King, G. M.: Characterization of root-associated methanotrophs from three freshwater macrophytes: Pontederia cordata, sparganium eurycarpum, and sagittaria latifolia, Appl. Environ. Microbiol., 64, 1099-1105, 1998.

Callaghan, T. V., Johansson, M., Key, J., Prowse, T., Ananicheva, M., and Klepikov A.: Chapter 11.1 Synthesis of feedbacks and interactions: From the cryosphere to the climate system - effects over various spatial and temporal scales, in: Snow, Water, Ice and Permafrost in the Arctic (SWIPA) 2011, Arctic Monitoring and Assessment Programme (AMAP), Oslo, Norway, 12 pp., 2011.

Chanton, J. P., Bauer, J. E., Glaser, P. A., Siegel, D. I., Kelley, C. A., Tyler, S. C., Romanowicz, E. H., and Lazrus, A.: Radiocarbon evidence for the substrates supporting methane formation within northern minnesota peatlands, Geochimica et Cosmochimica Acta, 59, 3663-3668, doi:10.1016/0016-7037(95)00240-z, 1995.

Christensen, T. R.: Methane emission from arctic tundra, Biogeochemistry, 21, 117-139, 1993.

Christensen, T. R., Friborg, T., Sommerkorn, M., Kaplan, J., Illeris, L., Søgaard, H., Nordstrøm, C., and Jonasson, S.: Trace gas exchange in a high-arctic valley, 1 . Variations in $\mathrm{CO}_{2}$ and $\mathrm{CH}_{4}$ flux between tundra vegetation types, Glob. Biogeochem. Cy., 14, 701-713, 2000.

Christensen, T. R., Ekberg, A., Ström, L., Mastepanov, M., Panikov, N., Öquist, M., Svensson, B. H., Nykanen, H., Martikainen, P. J., and Oskarsson, H.: Factors controlling large scale variations in methane emissions from wetlands, Geophys. Res. Lett., 30, 671-67-4, 2003a.

Christensen, T. R., Panikov, N., Mastepanov, M., Joabsson, A., Stewart, A., Oquist, M., Sommerkorn, M., Reynaud, S., and Svensson, B.: Biotic controls on $\mathrm{CO}_{2}$ and $\mathrm{CH}_{4}$ exchange in wetlands - a closed environment study, Biogeochemistry, 64, 337354, 2003 b.

Christensen T. R., Johansson, T., Åkerman, H. J., Mastepanov, M., Malmer, N., Friborg, T., Crill, P., and Svensson, B. H.: Thawing sub-arctic permafrost: Effects on vegetation and methane emissions, Geophys. Res. Lett., 31, L04501, doi:10.1029/2008JG000703, 2004.

Cicerone, R. J. and Shetter, J. D.: Sources of atmospheric methane measurements in rice paddies and a discussion, J. Geophys. Res., 86, 7203-7209, 1981.

ClimateBasis, The Zackenberg Database, http://zdb.dmu.dk, 2010.

Comas, X. and Slater, L.: Evolution of biogenic gases in peat blocks inferred from noninvasive dielectric permittivity measurements, Water Resour. Res., 43, W05424, doi:10.1029/2006wr005562, 2007.

Conrad, R.: Soil microorganisms as controllers of atmospheric trace gases $\left(\mathrm{H}_{2}, \mathrm{CO}, \mathrm{CH}_{4}, \mathrm{OCS}, \mathrm{N}_{2} \mathrm{O}\right.$, and $\left.\mathrm{NO}\right)$, Microbiol. Rev., 60, 609-640, 1996.

Daulat, W. E. and Clymo, R. S.: Effects of temperature and watertable on the efflux of methane from peatland surface cores, Atmos. Environ., 32, 3207-3218, 1998.
Dise, N. B., Gorham, E., and Verry, E. S.: Environmental factors controlling $\mathrm{CH}_{4}$ emissions from peatlands in northern Minnesota, J. Geophys. Res., 98, 583-594, 1993.

Elberling, B., Nordstrøm, C., Grøndahl, L., Søgaard, H., Friborg, T., Christensen, T.R. Ström, L., Marchand, F., and Nijs, I.: Higharctic soil $\mathrm{CO}_{2}$ and $\mathrm{CH}_{4}$ production controlled by temperature, water, freezing and snow, Elsevier Academic Press Inc, San Diego, Adv. Ecol. Res., 40, 441-472, 2008.

Friborg, T., Christensen, T. R., Hansen, B. U., Nordstrøm, C., and Søgaard, H.: Trace gas exchange in a high-arctic valley 2, Landscape $\mathrm{CH}_{4}$ fluxes measured and modeled using eddy correlation data, Global Biogeochem. Cy., 14, 715-723, 2000.

Glaser, P. H. and Chanton, J. P.: Methane accumulation and release from deep peat: measurements, conceptual models, and biogeochemical significance, in: Carbon Cycling in Northern PeatlandsBaird, edited by: A. J., Belyea, L. R., Comas, X., Reeve, A. S., and Slater, L. D., Washington DC, USA, American Geophysical Union, Geophys. Mono. Series, 184, 145-158, 2009.

Goulden, M. L. and Crill, P. M.: Automated measurements of $\mathrm{CO}_{2}$ exchange at the moss surface of a black spruce forest, Tree Physiology, 17, 537-542, 1997.

Grøndahl, L., Friborg, T., and Søgaard, H.: Temperature and snowmelt controls on interannual variability in carbon exchange in the high arctic, Theoret. Appl. Clim., 88, 111-125, 2007.

Grøndahl, L., Friborg, T., Christensen, T.R., Ekberg, A., Elberling, B., Illeris, L., Nordstrøm, C., Rennermalm, A., Sigsgaard, C., and Søgaard, H.: Spatial and inter-annual variability of trace gas fluxes in a heterogeneous high-arctic landscape, Elsevier Academic Press Inc, San Diego, Adv. Ecol. Res., 40, 473-498, 2008.

Hansen, B. U., Sigsgaard, C., Rasmussen, L., Cappelen, J., Hinkler, J., Mernild, S. H., Petersen, D., Tamstorf, M. P., Rasch, M., and Hasholt, B.: Present-day climate at Zackenberg, Elsevier Academic Press Inc, San Diego, Adv. Ecol. Res., 40, 111-149, 2008.

Hargreaves, K. J. and Fowler, D.: Quantifying the effects of water table and soil temperature on the emission of methane from peat wetland at the field scale - Season-long measurement by eddy correlation, Atmos. Environ., 32, 3275-3282, 1998.

Jackowicz-Korczynski, M., Christensen, T. R., Backstrand, K., Crill, P. M., Friborg, T., Mastepanov, M., and Ström, L.: Annual cycle of methane emission from a subarctic peatland, J. Geophys. Res., 115, G02009, doi:10.1029/2008JG000913, 2010.

Joabsson, A. and Christensen, T. R.: Methane emissions from wetlands and their relationship with vascular plants: An arctic example, Glob. Change Biol., 7, 919-932, 2001.

Joabsson, A., Christensen, T. R., and Wallén, B. : Vascular plant controls on methane emissions from northern peatforming wetlands, Trends Ecol. Evolut., 14, 385-388, 1999.

Johansson, T., Malmer, N., Crill, P. M., Friborg, T., Åkerman, J. H., Mastepanov, M., and Christensen, T. R.: Decadal vegetation changes in a northern peatland, greenhouse gas fluxes and net radiative forcing, Glob. Change Biol., 12, 2352-2369, 2006.

King, G. M.: Associations of methanotrophs with the roots and rhizomes of aquatic vegetation, Appl. Environ. Microbiol., 60, 3220-3227, 1994.

Lai, D. Y. F.: Methane dynamics in northern peatlands: A review, Pedosphere, 19, 409-421, 2009.

Liebner, S., Zeyer, J., Wagner, D., Schubert, C., Pfeiffer, E. M., and Knoblauch, C.: Methane oxidation associated with submerged brown mosses reduces methane emissions from Siberian polyg- 
onal tundra, J. Ecol., 99, 914-922, 2011.

Mastepanov, M. and Christensen, T. R.: Bimembrane diffusion probe for continuous recording of dissolved and entrapped bubble gas concentrations in peat, Soil Biol. Biochem., 40, 29923003, 2008.

Mastepanov, M. and Christensen, T. R.: Laboratory investigations of methane buildup in, and release from, shallow peats, in: Carbon Cycling in Northern Peatlands, edited by: Baird, A. J., Belyea, L. R., Comas, X., Reeve, A. S., and Slater, L. D., Washington DC, USA, American Geophysical Union, Geophys. Mono. Ser., 184, 205-218, 2009.

Mastepanov, M., Sigsgaard, C., Dlugokencky, E. J., Houweling, S., Ström L., Tamstorf, M. P., and Christensen, T. R.: Large tundra methane burst during onset of freezing, Nature, 456, 628-631, 2008.

Mastepanov, M., Sigsgaard, C., Tamstorf, M. P., and Christensen, T. R.: Modern automatic chamber technique as a powerful tool for trace gas flux monitoring, submitted, 2013.

McGuire, A. D., Christensen, T. R., Hayes, D., Heroult, A., Euskirchen, E., Kimball, J. S., Koven, C., Lafleur, P., Miller, P. A., Oechel, W., Peylin, P., Williams, M., and Yi, Y.: An assessment of the carbon balance of Arctic tundra: comparisons among observations, process models, and atmospheric inversions, Biogeosciences, 9, 3185-3204, doi:10.5194/bg-9-3185-2012, 2012.

Meltofte, H. and Rasch, M.: The study area at Zackenberg, Elsevier Academic Press Inc, San Diego, Adv. Ecol. Res., 40, 101-110, 2008.

Moore, T. R., De Young, A., Bubier, J. L., Humphreys, E. R., Lafleur, P. M., and Roulet, N. T.: A multi-year record of methane flux at the Mer Bleue bog, southern Canada, Ecosystems, 14, 646-657, doi:10.1007/s10021-011-9435-9, 2011.

Nordstrøm, C., Søgaard, H., Christensen, T. R., Friborg, T., and Hansen, B. U.: Seasonal carbon dioxide balance and respiration of a high-arctic fen ecosystem in NE-Greenland, Theor. Appl. Clim., 70, 149-166, 2001.

Panikov, N. S., Flanagan, P. W., Oechel, W. C., Mastepanov, M. A., and Christensen, T. R.: Microbial activity in soils frozen to below $-39{ }^{\circ} \mathrm{C}$, Soil Biology and Biochemistry, 38, 785-794, 2006.

Parmentier, F. J. W., van Huissteden, J., Kip, N., Op den Camp, H. J. M., Jetten, M. S. M., Maximov, T. C., and Dolman, A. J.: The role of endophytic methane-oxidizing bacteria in submerged Sphagnum in determining methane emissions of Northeastern Siberian tundra, Biogeosciences, 8, 1267-1278, doi:10.5194/bg-8-12672011, 2011a.

Parmentier, F. J. W., van Huissteden, J., van der Molen, M. K., Schaepman-Strub, G., Karsanaev, S. A., Maximov, T. C., and Dolman, A. J.: Spatial and temporal dynamics in eddy covariance observations of methane fluxes at a tundra site in northeastern Siberia, J. Geophys. Res.-Biogeosci., 116, G03016, doi:10.1029/2008JG000913, 2011b.

Pelletier, L., Moore, T. R., Roulet, N. T., Garneau, M., and Beaulieu-Audy, V.: Methane fluxes from three peatlands in the La Grande Riviere watershed, James Bay lowland, Canada, J. Geophys. Res.-Biogeosci., 112, 12 pp., 2007.

Rivkina, E. M., Friedmann, E. I., McKay, C. P., and Gilichinsky, D. A.: Metabolic activity of permafrost bacteria below the freezing point, Appl. Environ. Microbiol., 66, 3230-3233, 2000.

Sachs, T., Wille, C., Boike, J., and Kutzbach, L.: Environmental controls on ecosystem-scale $\mathrm{CH}_{4}$ emission from polygonal tun- dra in the Lena river delta, Siberia, J. Geophys. Res.-Biogeosci., 113, G00A03, doi:10.1029/2007JG000505, 2008.

Schuur, E. A. G., Vogel, J. G., Crummer, K. G., Lee, H., Sickman, J. O., and Osterkamp, T. E.: The effect of permafrost thaw on old carbon release and net carbon exchange from tundra, Nature, 459, 556-559, 2009.

Serreze, M. C., Walsh, J. E., Chapin, F. S., Osterkamp, T., Dyurgerov, M., Romanovsky, V., Oechel, W. C., Morison, J., Zhang, T., and Barry, R. G.: Observational evidence of recent change in the northern high-latitude environment, Clim. Change, 46, 159-207, doi:10.1023/a:1005504031923, 2000.

Skogland, T., Lomeland, S., and Goks $\varnothing y r$, J.: Respiratory burst after freezing and thawing of soil: Experiments with soil bacteria, Soil Biol. Biochem., 20, 851-856, 1988.

Søgaard, H., Nordstrøm, C., Friborg, T., Hansen, B. U., Christensen, T. R., and Bay, C.: Trace gas exchange in a high-arctic valley 3 , Integrating and scaling $\mathrm{CO}_{2}$ fluxes from canopy to landscape using flux data, footprint modeling, and remote sensing, Global Biogeochem. Cy., 14, 725-744, 2000.

Soulides, D. A. and Allison, F. E.: Effect of drying and freezing soils on carbon dioxide production, available mineral nutrients, aggregation, and bacterial population, Soil Science, 91, 291-298, 1961.

Strack, M. and Waddington, J. M.: Spatiotemporal variability in peatland subsurface methane dynamics, J. Geophys. Res.Biogeosci., 113, G02010, doi:10.1029/2007jg000472, 2008.

Ström, L., Ekberg, A., Mastepanov, M., and Christensen, T. R.: The effect of vascular plants on carbon turnover and methane emissions from a tundra wetland, Glob. Change Biol., 9, 1185-1192, 2003.

Ström, L., Mastepanov, M., and Christensen, T. R.: Species-specific effects of vascular plants on carbon turnover and methane emissions from wetlands, Biogeochemistry, 75, 65-82, 2005.

Ström, L., Tagesson, T., Mastepanov, M., and Christensen, T. R.: Presence of Eriophorum scheuchzeri enhances substrate availability and methane emission in an Arctic wetland, Soil Biol. Biochem., 45, 61-70, doi:10.1016/j.soilbio.2011.09.005, 2012.

Sturtevant, C. S., Oechel, W. C., Zona, D., Kim, Y., and Emerson, C. E.: Soil moisture control over autumn season methane flux, arctic coastal plain of Alaska, Biogeosciences, 9, 1423-1440, 2012, http://www.biogeosciences.net/9/1423/2012/.

Svensson, B. H. and Roswall, T.: In situ methane production from acid peat in plant communities with different moisture regimes in a subarctic mire, Oikos, 43, 341-350, 1984.

Tagesson, T., Molder, M., Mastepanov, M., Sigsgaard, C., Tamstorf, M. P., Lund, M., Falk, J. M., Lindroth, A., Christensen, T. R., and Strom, L.: Land-atmosphere exchange of methane from soil thawing to soil freezing in a high-arctic wet tundra ecosystem, Glob. Change Biol., 18, 1928-1940, doi:10.1111/j.13652486.2012.02647.x, 2012.

Tarnocai, C.: The effect of climate change on carbon in Canadian peatlands, Glob. Planet. Change, 53, 222-232, 2006.

Tarnocai, C., Nixon, F. M., and Kutny, L.: CircumpolarActive-Layer-Monitoring (CALM) sites in the Mackenzie valley, northwestern Canada, Permafrost Periglac., 15, 141-153, doi:10.1002/ppp.490, 2004.

Tokida, T., Miyazaki, T., Mizoguchi, M., and Seki, K.: In situ accumulation of methane bubbles in a natural wetland soil, Eur. J. Soil Sci., 56, 389-396, 2005. 
Treat, C. C., Bubier, J. L., Varner, R. K., and Crill, P. M.: Timescale dependence of environmental and plant-mediated controls on $\mathrm{CH}_{4}$ flux in a temperate fen, J. Geophys. Res.-Biogeosci., 112, G01014, doi:10.1029/2007JG000505, 2007.

Whalen, S. C.: Biogeochemistry of methane exchange between natural wetlands and the atmosphere, Environ. Engineer. Sci., 22, 73-94, 2005.

Whalen, S. C. and Reeburgh, W. S.: Consumption of atmospheric methane by tundra soils, Nature, 346, 160-162, 1990.
Wilhelm, E., Battino, R., and Wilcock, R. J.: Low-pressure solubility of gases in liquid water, Chemical Reviews, 77, 219-262, 1977.

Wille, C., Kutzbach, L., Sachs, T., Wagner, D., and Pfeiffer, E. M.: Methane emission from siberian arctic polygonal tundra: Eddy covariance measurements and modeling, Global Change Biology, 14, 1395-1408, doi:10.1111/j.1365-2486.2008.01586.x, 2008.

Zimov, S. A., Schuur, E. A. G., and Chapin, F. S.: Permafrost and the global carbon budget, Science, 312, 1612-1613, 2006. 